\title{
OBSERVATIONS ON LUMINESCENCE IN PELAGIC ANIMALS
}

\author{
By J. A. C. NicoL \\ The Plymouth Laboratory \\ (Plate I and Text-figs. I-I9)
}

Luminescence is very common among marine animals, and many species possess highly developed photophores or light-emitting organs. It is probable, therefore, that luminescence plays an important part in the economy of their lives. A few determinations of the spectral composition and intensity of light emitted by marine animals are available (Coblentz \& Hughes, 1926; Eymers \& van Schouwenburg, 1937; Clarke \& Backus, I956; Kampa \& Boden, 1957; Nicol, $1957 b, c, 1958 a, b)$. More data of this kind are desirable in order to estimate the visual efficiency of luminescence, distances at which luminescence can be perceived, the contribution it makes to general background illumination, etc. With such information it should be possible to discuss more profitably such biological problems as the role of luminescence in intraspecific signalling, sex recognition, swarming, and attraction or repulsion between species. As a contribution to this field I have measured the intensities of light emitted by some pelagic species of animals.

Most of the work to be described in this paper was carried out during cruises of R. V. 'Sarsia' and R.R.S. 'Discovery II' (Marine Biological Association of the United Kingdom and National Institute of Oceanography, respectively). Collections were made at various stations in the East Atlantic between $30^{\circ} \mathrm{N}$. and $48^{\circ} \mathrm{N}$. The apparatus for measuring light intensities was calibrated ashore at the Plymouth Laboratory; measurements of animal light were made at sea. In addition to the physical measurements, some histological descriptions of the light organs of several species are presented, together with miscellaneous observations on regulation of flashing in several species.

\section{MATERIALS AND METHODS}

Animals were captured in vertical and oblique hauls with a $2 \mathrm{~m}$ stramin net or ring trawl (R.T.), or with an Isaacs Kidd trawl (I.K.T.); and in surface hauls with a I m stramin net (N. I00).

Stations were as follows.

'Discovery' stations:

No. 3344. I8 Oct. I955. $41^{\circ} 16^{\prime}-17 \frac{1}{2}^{\prime}$ N., $9^{\circ} 28^{\prime}$ W. R.T. oblique. $1000 \mathrm{~m}$ of wire out, estimated depth $500 \mathrm{~m}$. 
No. 3354.6 Nov. $1955.31^{\circ} 12 \cdot 5^{\prime}$ N., $15^{\circ} 58^{\prime} \mathrm{W}$. to $31^{\circ} 14 \cdot 5^{\prime} \mathrm{N}$., $16^{\circ}$ oI $\cdot 5^{\prime} \mathrm{W}$. R.T. oblique; estimated depth $250 \mathrm{~m}$.

No. 3355. 8 Nov. $1955.30^{\circ} 13^{\prime}$ N., $15^{\circ} 58^{\prime}$ W. R.T. surface.

No. 3365 . I8 Feb. I956. $43^{\circ} 47 \cdot 2^{\prime}$ N., I3 ${ }^{\circ} 8 \cdot 6^{\prime} \mathrm{W}$. R.T. oblique. I500 $\mathrm{m}$ of wire out; estimated depth about $1000 \mathrm{~m}$.

No. 3366. I9 Feb. I956. $4 \mathrm{I}^{\circ} \mathrm{II} \mathrm{I}^{\prime} \mathrm{N}$., I4 ${ }^{\circ} 35^{\prime}$ W. R.T. oblique. $2000 \mathrm{~m}$ of wire out; estimated depth about $1300 \mathrm{~m}$.

No. 3368. 2I Feb. 1956. $4 \mathrm{I}^{\circ} \mathrm{0} 3^{\prime}$ N., I4 ${ }^{\circ} 23^{\prime}$ W. R.T. oblique. $2000 \mathrm{~m}$ of wire out; estimated depth about $1300 \mathrm{~m}$.

No. 3369. 24 Feb. 1956. $38^{\circ} 39^{\prime}$ N., $9^{\circ} 40 \cdot 5^{\prime}$ W. N. roo surface.

No. 3372 . $28 \mathrm{Feb}$. 1956. $4 \mathrm{I}^{\circ} 09^{\prime} \mathrm{N}$., $14^{\circ} 35^{\prime} \mathrm{W}$. R.T. oblique. $3000 \mathrm{~m}$ of wire out; estimated depth about $2000 \mathrm{~m}$.

No. 3374. 29 Feb. I956. $4 \mathrm{I}^{\circ} \mathrm{II}^{\prime} \mathrm{N}$., I4 ${ }^{\circ} 34^{\prime}$ W. R.T. oblique. $3000 \mathrm{~m}$ of wire out; estimated depth about $2000 \mathrm{~m}$.

No. 3375. 2 Mar. I956. $4 \mathrm{I}^{\circ} \mathrm{og}^{\prime} \mathrm{N}$., $14^{\circ} 33^{\prime}$ W. R.T. oblique. $3000 \mathrm{~m}$ of wire out; estimated depth about $2000 \mathrm{~m}$.

No. 3376 . 6 Mar. 1956. $46^{\circ} 59 \cdot 5^{\prime}$ N., $7^{\circ} 54^{\prime} 5^{\prime}$ W. R.T. oblique. $3000 \mathrm{~m}$ of wire out; estimated depth about $2000 \mathrm{~m}$.

\section{'Sarsia' stations:}

No. I, cruise 6/55. I7 June 1955. $46^{\circ} 49^{\prime}$ N., $5^{\circ} 44^{\prime}$ W. R.T. vertical. $280 \mathrm{~m}$ of wire out.

No. 5 , cruise $3 / 57.20$ June 1957. $46^{\circ} 55^{\prime}$ N., $5^{\circ} 57^{\prime}$ W. I.K.T. oblique. I $800 \mathrm{~m}$ of wire out; estimated depth about $1200 \mathrm{~m}$.

No. 6 , cruise 3/57. 20 June 1957. $47^{\circ} 07^{\prime}$ N., $6^{\circ} 06^{\prime}$ W. R.T. vertical haul. I $829 \mathrm{~m}$ of wire out.

No. 8, cruise 3/57. 20/2I June 1957. $47^{\circ} 00^{\prime}$ N., $6^{\circ} 05^{\prime}$ W. Hand nets. Surface.

No. IO, cruise $3 / 57$. 2 I June $1957.46^{\circ} 57^{\prime}$ N., $6^{\circ}$ o $9^{\prime}$ W. I.K.T. oblique. I $800 \mathrm{~m}$ of wire out; estimated depth about 1200 .

No. 2 I, cruise 3/57. 28 June 1957. $46^{\circ} 47^{\prime}$ N., $5^{\circ} 56^{\prime}$ W. R.T. oblique. $2742 \mathrm{~m}$ of wire out; estimated depth about $1800 \mathrm{~m}$.

No. 23 , cruise $3 / 57.29$ June I957. $46^{\circ} 42^{\prime}$ N., $6^{\circ} 22^{\prime}$ W. I.K.T. oblique. $1800 \mathrm{~m}$ of wire out; estimated depth $1000 \mathrm{~m}$.

The animals were examined either immediately on capture, or they were retained in cold sea water in a refrigerator for several hours. Some measurements were made of animals at room temperature $\left(>\mathrm{I} 4^{\circ} \mathrm{C}\right)$, but it was found that animals from deep waters survived better when placed in cooled sea water. Accordingly, an arrangement was devised for delivering cooled sea water to the vessel containing the animal, and this arrangement was used for deep-sea species. The method consisted of taking sea water from the ship's system, and passing it through a lead coil lying in a refrigerator. A visual indicator was placed in the circulation to monitor flow-rate. Water temperatures were noted for each experiment, and are given in the text.

Measurements of spectral composition and intensity were made by means of a multiplier phototube (E.M.I. type no. 6685). The photomultiplier was connected to a cathode-ray oscilloscope having a d.c. amplifier. Mains supply for the photomultiplier and oscilloscope was regulated by a voltage stabilizer. 
Occasionally two oscilloscopes were used, having different amplifications. Deflexions on the oscilloscope screen were photographed on moving paper. A time scale was provided by a periodically flashing light, regulated by a Palmer relay.

The spectral sensitivity of the photomultiplier (type no. 6685) had been determined by the National Physical Laboratory; a curve is given elsewhere (Nicol, I958a, fig. 2A). The photomultiplier was calibrated against a substandard lamp (supplied by the National Physical Laboratory). From the data a constant, $q$, was calculated, such that $q / S_{\lambda}=\mathrm{W} / \mathrm{cm}^{2}$ of a given wavelength $(\lambda)$ required to produce unit deflexion

$$
\begin{aligned}
q & =\frac{p}{D_{L}} \int_{400}^{700} \mathcal{F}_{\lambda} S_{\lambda} T_{\lambda} \mathrm{d} \lambda \mathrm{W} / \mathrm{cm}^{2} \text { receptor surface, } \\
& =0.49 \times 10^{-12} \mathrm{~W} / \mathrm{cm}^{2} \text { receptor surface. }
\end{aligned}
$$

$S_{\lambda}=$ relative sensitivity of photomultiplier E.M.I. type no. 6685 at a given wavelength; $\mathscr{F}_{\lambda}$ is the spectral energy distribution of the substandard lamp; $T_{\lambda}$ is the transmission of neutral filters used in the measurements; $D_{L}$ is the deflexion occasioned by the substandard lamp on the cathode-ray oscilloscope at a given amplification; and $p$ is a quantity for the particular experimental set-up. The method and calculations are described in more detail elsewhere (Nicol, 1958a).

For daily checks on the sensitivity of the apparatus at sea, a stable light source was employed, which consisted of a stilbene phosphor irradiated by ${ }^{60} \mathrm{Co}$ (supplied by the United Kingdom Atomic Energy Authority). This source had a measured output of $0.07 \mu \mathrm{lm}$.

Spectral sensitivity was determined by a method making use of a rotating disc containing alternating spectral and reference filters about its circumference. Spectral filters were Ilford gelatine and Chance glass. Reference filters were Ilford blue-green 603 or Ilford green 604. Two discs were used, containing the filters listed in Table $\mathrm{I}$, in order of rotation. Disc I was intended for analysing green light, Disc II for blue light. Curves for the combined effect of filter transmission $\left(T_{\lambda}\right)$ and photomultiplier sensitivity $\left(S_{\lambda}\right)$ are given in Text-figs. I and $2\left(S_{\lambda} T_{\lambda}\right.$ plotted against $\left.\lambda\right)$. The luminescent flashes vary greatly in intensity, and the responses obtained with the reference filters gave periodical values for fluctuating flash intensity. First approximate results for relative spectral composition of luminescent light were corrected for wide band-width of the filters. The method is described in more detail in earlier papers (Nicol, $1957 b, c)$.

When measuring intensity, the animal was placed at a known distance directly beneath the photomultiplier. When measuring spectral emission, the rotating disc was aligned close beneath the photocathode, so that each filter in turn passed across the face of the latter. The animal was placed as close as 
possible to the disc, vertically underneath the end window of the photomultiplier (see Nicol, I957c, fig. I). The species from which luminescence was recorded are listed in Table 2.

For studying regulation of luminescence, controlled electrical stimulation was employed, either condenser shocks or square wave pulses. Electrodes were $\mathrm{Ag}$, Pt, sometimes non-polarizable $\mathrm{Ag} / \mathrm{AgCl}$. Some earlier recordings were made with an R.C.A. photomultiplier, type no. 93I A, with battery supply; extracts of these records have already been published (Nicol, 1955a). Later observations were made with E.M.I. photomultiplier, type no. 6685 .

Particulars concerning chemistry and histology are given in the text.

\section{TABLE 1. FILTERS IN ORDER OF ROTATION}

\section{Disc I}

Double space (position marker)

Ilford blue-green $603+$ neutral density $\mathrm{D} 0.5$

Ilford red 608

Ilford blue-green $603+$ neutral density D 0.5

Ilford orange 607

Ilford blue-green 603 + neutral density D 0.5

Ilford yellow 606

Ilford blue-green $60_{3}$ + neutral density $\mathrm{D} 0.5$

Ilford yellow green 605

Ilford blue-green $60_{3}$ + neutral density D 0.5

Ilford green $604+$ neutral density D 0.5

Ilford blue-green 603 + neutral density

D 0.5

Ilford blue 602 + neutral density

D 0.5

Ilford blue-green 603 + neutral density D 0.5

Ilford violet 601

Ilford blue-green 603 + neutral density D 0.5
Disc II

Double space (position marker)

Ilford green 604

Ilford orange 607

Ilford green 604

Ilford yellow 606

Ilford green 604

Ilford yellow-green 605

Ilford green 604

Ilford blue-green 603 + neutral density D 0.5

Ilford green 604

Ilford blue $602+$ neutral density

$\mathrm{D} 0.5$

Ilford green 604

Ilford violet 601

Ilford green 604

Chance purple OVI

Ilford green 604

Chance u.v. OX

\section{OBSERVATIONS AND RESULTS}

In order to calculate radiant flux, a curve for relative spectral emission is required $\left(E_{\lambda}\right.$ plotted against $\left.\lambda\right)$. This curve is then put on an absolute basis in terms of a quantity $r$, such that $E_{\lambda} r$ gives $\mathrm{W} / \mathrm{cm}^{2}$ of receptor surface $/ \mathrm{m} \mu$ under the experimental conditions specified.

$$
\begin{aligned}
& r=\frac{D q}{E_{\lambda} S_{\lambda} \mathrm{d} \lambda} \mathrm{W} / \mathrm{cm}^{2} / \mathrm{m} \mu, \\
& r=D \times \frac{0.49 \times \mathrm{IO}^{-12}}{E_{\lambda} S_{\lambda} \mathrm{d} \lambda} \mathrm{W} / \mathrm{cm}^{2} / \mathrm{m} \mu .
\end{aligned}
$$

Data for various species, and calculated values of light intensities, are assembled in Table 2. Details are presented in the following sections, arranged according to zoological classification. 
Radiolaria. Two specimens were examined belonging to the species Cytocladus major Schröder and Aulosphaera triodon Haeckel ('Discovery' Sta. no. 3375). Both specimens were spherical in shape and about the same diameter (some $12 \mathrm{~mm}$ ). That they were two separate species was not apparent at the time, and the records of their luminescence were not distinguished from each other. Results for both specimens are combined.

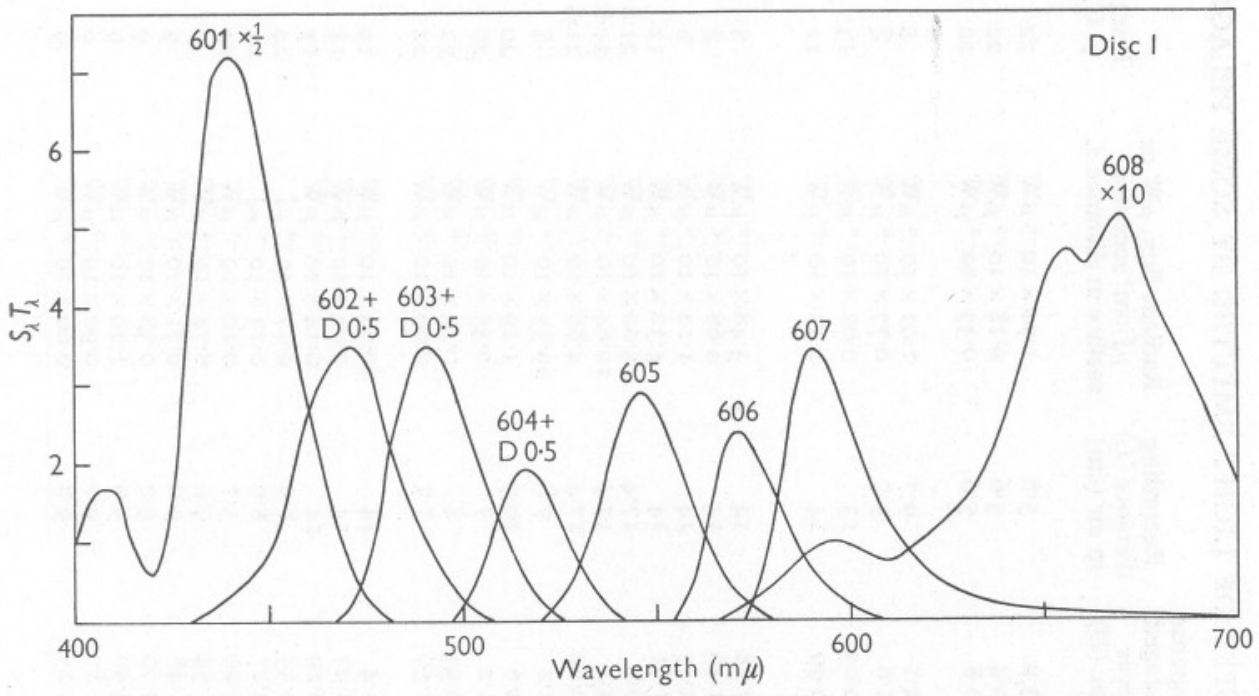

Text-fig. I. Curves showing the combined effect of sensitivity of the photomultiplier $\left(S_{\lambda}\right)$ times transmission of spectral filters $\left(T_{\lambda}\right)$ used in recording Disc I $\left(S_{\lambda} T_{\lambda}\right.$ plotted against $\left.\lambda\right)$. Neutral filters, having a density of 0.5 , were used in conjunction with Ilford spectral filters, nos. 602,603 and 604 .

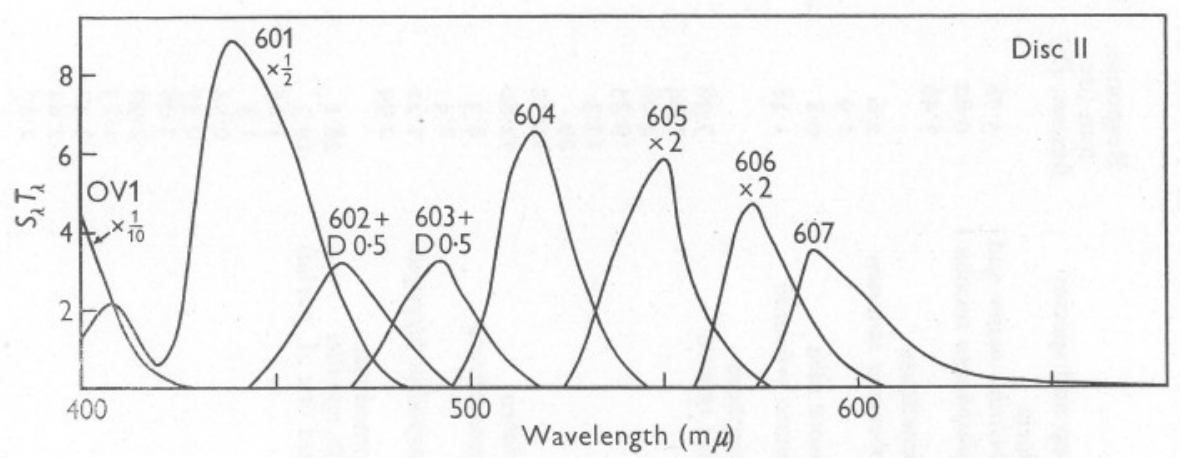

Text-fig. 2. Curves showing the combined effect of sensitivity of the photomultiplier $\left(S_{\lambda}\right)$ times transmission of spectral filters $\left(T_{\lambda}\right)$ used in recording Disc II $\left(S_{\lambda} T_{\lambda}\right.$ plotted against $\left.\lambda\right)$. Neutral filters, having a density of 0.5 , were used in conjunction with Ilford spectral filters, nos. 602 and 603 . 
TABLE 2. CALCULATIONS OF THE INTENSITY OF LIGHT EMITTED BY SOME PELAGIC ANIMALS

Group and species

Radiolaria

Cytocladus major and

Aulosphaera triodon $\}$

Hydromedusae

Colobonema sericeum

Crossota alba

Aeginura grimaldii

Siphonophora

Vogtia spinosa

4.08
19.35
13.3
29
14.52

V. glabra

Rosacea plicata

\section{Hippopodius hippopus}

Scyphomedusae

Atolla wyvillei

(and one A.parua)

I. 48

$5 \cdot 78$

0.82

I. 45

$2 \cdot 6$

$\mathrm{I} \cdot 9$
0.8

$7 \cdot 98$

I. 94

$19 \cdot 35$

4.52

$72 \cdot 80$

$6 \cdot 3$

$2 \cdot 4$

$\mathrm{I} \cdot 22$
$2 \cdot 99$

28. I

$\begin{array}{cc}\text { Response, } & \begin{array}{c}\text { Response } \\ \text { mm (de- } \\ \text { duration }\end{array} \\ \left.\text { flexion, } D_{s}\right) & (\mathrm{sec})\end{array}$

averaged

over

Recording

distance $(L)$

I $\sec (D)$

in air $(\mathrm{cm})$

$\mu \mathrm{J} / \mathrm{cm}^{2}$ receptor

surface at distance $L$

Temp.

ca. $\mathrm{I}$

$19 \cdot 3$
$I \cdot 25$

I. 25

I. 3

0.54

0.35

3.08

$2 \cdot 96$

I. I3

3.42
2.84

$2 \cdot 27$
2.7

$\mathrm{I} \cdot \mathrm{I}$
$\mathrm{I} \cdot 7$

I.9

I.9

$3 \cdot 8$

I I 2

I. 9

$3 \cdot I$
$3 \cdot 8$

$3 \cdot 8$
$3 \cdot 3$

$2 \cdot 9$

$2 \cdot 9$

$3 \cdot 5$

I.9

I

I

I. 6

I. 4

O.I4

0.6

0.5

I.O

$\begin{array}{lc}3.9 & 5.6 \\ 0.4 & 5.6 \\ 0.8 & 5.6 \\ & \\ 2.1 & 9.7 \\ 1.6 & 9.7 \\ 0.05 & 13 \\ 0.99 & 14\end{array}$

$$
\begin{aligned}
& \mathrm{I} \cdot 70 \times 10^{-6} \mu \mathrm{W} \\
& 0 . \mathrm{I} 8 \times 10^{-6} \mu \mathrm{W} \\
& 0.35 \times 10^{-6} \mu \mathrm{W} \\
& \\
& \mathrm{I} \cdot 0 \mathrm{I} \times 10^{-6} \mu \mathrm{W} \\
& 0.77 \times 10^{-6} \mu \mathrm{W} \\
& 0.02 \times 10^{-6} \mu \mathrm{W} \\
& 0.47 \times 10^{-6} \mu \mathrm{W}
\end{aligned}
$$

$7 \cdot 58$

I. 49
$2 \cdot 45$

$2 \cdot 45$

I I. 6 I

I0.9

$23 \cdot 2$

I0.60

$42 \cdot 2$

$2 \cdot 6$

I. 2

0.93

I.5O

$2 \mathrm{I} \cdot 4$

$8 \cdot 27$

0.29

0.35

0.27

0.20

I. 54

I. 48

0.79

2.50

I. 87
I. 25

I. 25
$3.48 \times 10^{-6} \mu \mathrm{W}$

$0.68 \times$ IO $^{-6} \mu \mathrm{W}$

$\mathrm{I} \cdot \mathrm{I} 2 \times \mathrm{IO}^{-6} \mu \mathrm{W}$

$5.32 \times 10^{-6} \mu \mathrm{W}$

$5.00 \times \mathrm{IO}^{-6} \mu \mathrm{W}$

I0. $64 \times$ IO $^{-6} \mu \mathrm{W}$

$4.86 \times \mathrm{IO}^{-6} \mu \mathrm{W}$

I9. $35 \times \mathrm{IO}^{-6} \mu \mathrm{W}$

$\mathrm{I} \cdot \mathrm{I} 9 \times \mathrm{IO}^{-6} \mu \mathrm{W}$

$0.55 \times \mathrm{IO}^{-6} \mu \mathrm{W}$

$0.43 \times 10^{-6} \mu \mathrm{W}$

$0.69 \times \mathrm{IO}^{-6} \mu \mathrm{W}$

IO. $24 \times \mathrm{IO}^{-6} \mu \mathrm{W}$

$3.96 \times \mathrm{IO}^{-6} \mu \mathrm{W}$

$0 . \mathrm{I} 4 \times \mathrm{IO}^{-6} \mu \mathrm{W}$

$0.17 \times \mathrm{IO}^{-6} \mu \mathrm{J}$

$0.13 \times 10^{-6} \mu \mathrm{J}$

$0.10 \times \mathrm{IO}^{-6} \mu \mathrm{W}$

$0.74 \times \mathrm{IO}^{-6} \mu \mathrm{W}$

$0.7 \mathrm{I} \times \mathrm{IO}^{-6} \mu \mathrm{W}$

$0.38 \times 10^{-6} \mu \mathrm{W}$

$\mathrm{I} \cdot 20 \times \mathrm{IO}^{-6} \mu \mathrm{W}$

$0.90 \times \mathrm{IO}^{-6} \mu \mathrm{W}$

$0.60 \times \mathrm{IO}^{-6} \mu \mathrm{W}$

$\begin{array}{ll}22 & \mathrm{I} \cdot 2 \mathrm{~cm} \text { diam. } \\ 22 & \mathrm{I} \cdot 2 \mathrm{~cm} \text { diam. } \\ 22 & \mathrm{I} \cdot 2 \mathrm{~cm} \text { diam. }\end{array}$

8

$4 \mathrm{~cm}$ diam

$4 \mathrm{~cm}$ diam.

$2.5 \mathrm{~cm}$ diam.

ca. $\mathrm{I} \cdot \mathbf{2} \mathrm{cm}$ diam.

$2 \mathrm{~cm}$ diam.

$2 \mathrm{~cm}$ diam.

$2 \mathrm{~cm}$ diam.

$2 \mathrm{~cm}$ diam.

I $\mathrm{cm}$ diam.

I $\mathrm{cm}$ diam.

I $\mathrm{cm}$. diam.

$2 \mathrm{~cm}$ diam.

$2.5 \mathrm{~cm}$ diam.

$2.5 \mathrm{~cm}$ diam.

$0.8 \times 0.3 \mathrm{~cm}$

$\mathrm{I} \cdot 3 \mathrm{~cm}$ diam.

$9 \mathrm{~cm}$ diam.

$9 \mathrm{~cm}$ diam.

$9 \mathrm{~cm}$ diam.

$5 \mathrm{~cm}$ diam.

$5 \mathrm{~cm}$ diam.

$\mathrm{I} \cdot 2 \mathrm{~cm}$ diam

$2.7 \mathrm{~cm}$ diam.

$2.7 \mathrm{~cm}$ diam.

$2 \cdot 7 \mathrm{~cm}$ diam.

$2.7 \mathrm{~cm}$ diam.

$2.7 \mathrm{~cm}$ diam.

$2.7 \mathrm{~cm}$ diam. 


$29 \cdot 3$
$11 \cdot 8$
$70 \cdot 2$
83.6
$6 \cdot 7$
$53^{\star} \cdot 6^{\star}$
$300^{\star}$
$66 \cdot 3$
13.8
34.4
4.6

13.8

Crustacea

Tunicata

Teleostei
Acanthephyra purpurea

Pyrosoma atlanticum

Myctophum punctatum

\section{$0 \cdot 9$} $2 \cdot 9$ $2 \cdot 4$

$2 \cdot 6$
$10 \cdot 8$ 10.8
5.5
8.3 8.3

$35 \cdot 4$

0.56
I $1 \cdot 97$

II $\cdot 97$
I.03

$\mathrm{I} \cdot 88$

$I \cdot 71$
25.65

Searsia schnakenbecki

S. koefoedi
57

57
150

55

321
245

\begin{tabular}{|c|c|}
\hline 0.8 & $17 \cdot 6$ \\
\hline 0.8 & 3.9 \\
\hline 0.18 & 28.8 \\
\hline 0.6 & $27 \cdot 8$ \\
\hline 0.1 & 2.5 \\
\hline I & I6. $4^{\star}$ \\
\hline $\mathrm{I} \cdot 6$ & $200^{\star}$ \\
\hline 0.5 & $26 \cdot 5$ \\
\hline D. 7 & 6.9 \\
\hline 0.8 & $22 \cdot 4$ \\
\hline 0.3 & $I \cdot 5$ \\
\hline 0.3 & $I \cdot 9$ \\
\hline I & 0.5 \\
\hline & $I \cdot 0$ \\
\hline & $2 \cdot 2$ \\
\hline
\end{tabular}

$\begin{array}{ll}4.7 & 2.5 \\ 2.3 & 4.8\end{array}$

$\begin{array}{ll}4 \cdot 3 & 4.8 \\ I \cdot 7 & 3.6\end{array}$

17

I I

$3 \cdot 6$

35

\section{9}

$2 \cdot 0$
$I$

I

0.42

$4 \cdot 23$

2

$2 \cdot 3$

$3 \cdot 9$

0.20

$7 \cdot 06$
0.51

0.47

0.42

12.83

36

36

100

37
245

245
184
* Deflexion off screen. Rough estimate.

+ Standard length.

$28 \cdot 4$
$28 \cdot 2$
26
$26 \cdot 9$
$24 \cdot 4$
$34 \cdot 4$
$26 \cdot 9$
$26 \cdot 9$
$26 \cdot 9$
$27 \cdot 4$
$13 \cdot 8$
$13 \cdot 8$
9
9
9

\section{I0. 8}

$20 \cdot 8$

$20 \cdot 8$

27

$28 \cdot 3$

9.5

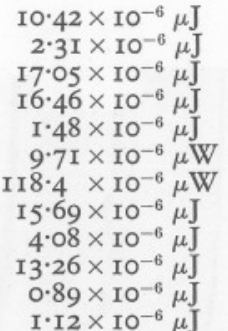

$\mathrm{I} \cdot \mathrm{I} 2 \times 10^{-6} \mu \mathrm{J}$

$0.23 \times 10^{-6} \mu \mathrm{W}$ $0.46 \times 10^{-6} \mu \mathrm{W}$ $\mathrm{I} \cdot \mathrm{OI} \times \mathrm{IO}^{-6} \mu \mathrm{W}$

$\mathrm{I} \cdot \mathrm{I} 8 \times 1 \mathrm{O}^{-6} \mu \mathrm{W}$ $2 \cdot 3 \times 10^{-6} \mu \mathrm{W}$ $3.7 \times 10^{-6} \mu \mathrm{W}$

I7 $\times 10^{-6} \mu \mathrm{W}$

$0.09 \times 10^{-6} \mu \mathrm{J}$

$3.20 \times 10^{-6} \mu \mathrm{W}$

$0.23 \times 10^{-6} \mu \mathrm{W}$

$0.2 \mathrm{I} \times 10^{-6} \mu \mathrm{W}$

$0.19 \times 10^{-6} \mu \mathrm{J}$

I9 $\times \mathrm{IO}^{-6} \mu \mathrm{W}$

$53 \times 10^{-6} \mu \mathrm{W}$

$20 \times 10^{-6} \mu \mathrm{W}$

$\begin{array}{rrr}\mathrm{I}_{4} .7 & 130 & \times \mathrm{IO}^{-6} \mu \mathrm{W} \\ \mathrm{I} 4.7 & 98 & \times \mathrm{IO}^{-6} \mu \mathrm{W}\end{array}$
I4 I $\times I .2 \mathrm{~cm}$ II $\quad \mathrm{I} \times \mathrm{I} \cdot 2 \mathrm{~cm}$ $24.5 \quad \mathrm{I} \times \mathrm{I} .5 \mathrm{~cm}$ $24.5 \quad \mathrm{I} \times \mathrm{I} .5 \mathrm{~cm}$ $\mathrm{I} \times \mathrm{I} .5 \mathrm{~cm}$ $\mathrm{I} \times \mathrm{I} \cdot 5 \mathrm{~cm}$ $\mathrm{I} \times \mathrm{I} \cdot 5 \mathrm{~cm}$ I $\times I .5 \mathrm{~cm}$ $\mathrm{I} \times \mathrm{I} \cdot 5 \mathrm{~cm}$ $\mathrm{I} \times \mathrm{I} \cdot 5 \mathrm{~cm}$ $2 \times 4 \mathrm{~cm}$ $2 \times 4 \mathrm{~cm}$

9

I $\times 4 \mathrm{~cm}$ $\mathrm{I} \cdot 2 \times 6 \mathrm{~cm}$ I $\times 4 \mathrm{~cm}$ $0.9-\mathrm{I} \cdot 2 \times 4.4 \mathrm{~cm}$

$88 \mathrm{~mm}$ long $88 \mathrm{~mm}$ long $85 \mathrm{~mm}$ long $85 \mathrm{~mm}$ long $89 \mathrm{~mm}$ long $89 \mathrm{~mm}$ long I2. $7 \mathrm{~cm}$ longt $12.7 \mathrm{~cm}$ long
$12.7 \mathrm{~cm}$ long† $12.2 \mathrm{~cm}$ long $12.2 \mathrm{~cm}$ long $\dagger$ 
Both radiolarians gave a luminescent glow, lasting some I-2 sec when subjected to tactile stimulation (Text-fig. $3 \mathrm{~A}, \mathrm{~B}, \mathrm{C}$ ). The light had a bluish colour and it illuminated the whole sphere, although it appeared brightest at the centre. Neither of these two species has hitherto been reported to be luminescent (cf. Harvey, 1952). The light of other radiolarians is blue and of low intensity (Brandt, I885; Harvey, 1955).

Light intensity of Cytocladus major and Aulosphaera triodon, measured at a distance of $5.6 \mathrm{~cm}$ in air, ranged from $0.2 \times 10^{-6}$ to $\mathrm{I} \cdot 7 \times 10^{-6} \mu \mathrm{W} / \mathrm{cm}^{2}$

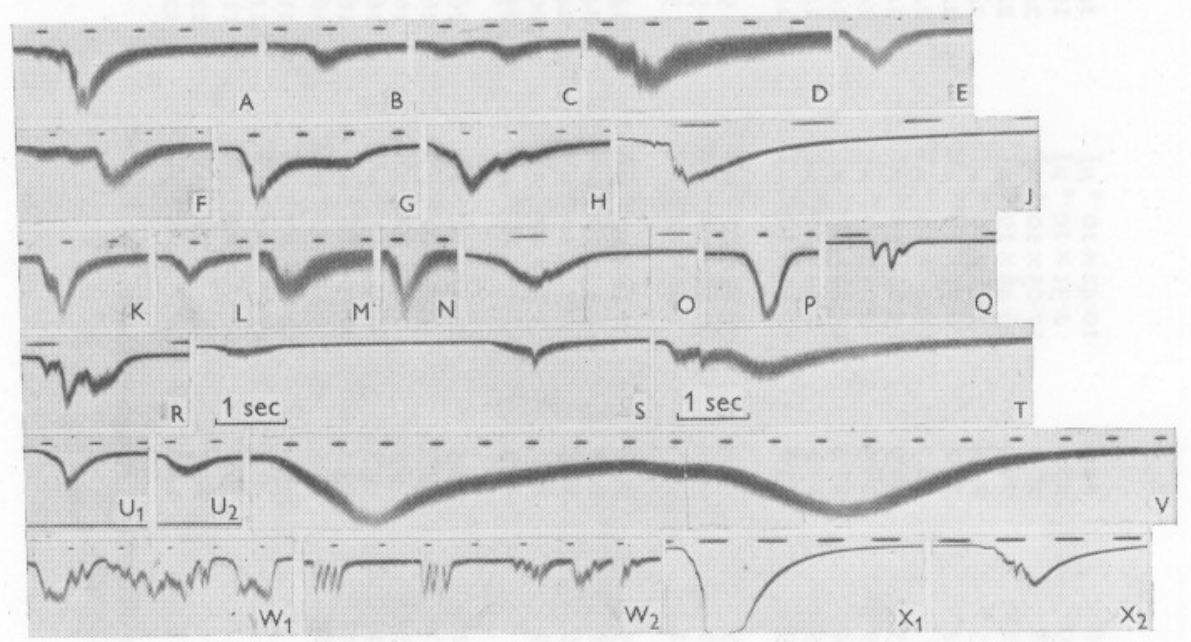

Text-fig. 3. Oscillograph records of the luminescent responses of pelagic animals. Deflexion downwards of the oscilloscope beam corresponds to the luminescent glow or flash. Periodical time scale above. A-C. Flashes of radiolarians (Cytocladus major and Aulosphaera triodon), evoked by mechanical stimulation. Water temperature, $22^{\circ} \mathrm{C}$. Time scale, period $0.96 \mathrm{sec}$. D. Aeginura grimaldii. Glow evoked by mechanical stimulation. Temperature of sea water I I $^{\circ}$ C. Time scale, period $0.97 \mathrm{sec}$. E, F. Responses of Colobonema sericeum to mechanical stimulation. Time, $\mathrm{I} / \mathrm{sec}$. Temperature of sea water $8^{\circ} \mathrm{C}$. G, H. Flashing of Vogtia spinosa under mechanical stimulation. Time scale, period $0.98 \mathrm{sec}$. Temperatures of sea water: $\mathrm{G}, \mathrm{I} 2^{\circ} \mathrm{C}$, H, $2 \mathrm{I} \cdot 8^{\circ} \mathrm{C}$. J. Vogtia glabra. Luminescence evoked by mechanical stimulation. Time scale, I $/ \mathrm{sec}$. Temperature of sea water $8^{\circ} \mathrm{C}$. K, L. Luminescence of Rosacea plicata evoked by mechanical stimulation. Time scale, period $0.96 \mathrm{sec}$. Temperature of sea water $20^{\circ} \mathrm{C}$. M, N. Hippopodius hippopus (Forskål). Luminescent responses resulting from mechanical stimuli. Time scale, I/sec. Water temperature about $22^{\circ} \mathrm{C}$. O, P. Flashes of Atolla wyvillei under mechanical stimulation. Time, I/sec. Water temperature $\mathrm{II}^{\circ} \mathrm{C}$. Q, R. Flashes of Beroë ovata subjected to mechanical stimulation. Time scale, period $0.96 \mathrm{sec}$. Temperature of sea water, $24^{\circ} \mathrm{C}$ (Q), $\mathrm{II}^{\circ} \mathrm{C}(\mathrm{R})$. S, T. 'Puffs' of light produced by the luminous discharge of a deep-sea shrimp, Acanthephyra purpurea. Luminescence was provoked by tactile stimulation. Time scale, I sec. Temperature of sea water, $9^{\circ} \mathrm{C}$. Amplification of $\mathrm{s} 0.58$ times that of $\mathrm{T}$. $\mathrm{U}_{1}, \mathrm{U}_{2}$. Pyrosoma atlanticum. Glow produced by mechanical stimulation of whole animal ( $6 \mathrm{~cm} \mathrm{long}$ ). Time, I/sec. Water temperature, $24.5^{\circ} \mathrm{C}$. v. Pyrosoma atlanticum. Glow following mechanical stimuli (animal $4 \mathrm{~cm}$ long). Time period, $0.96 \mathrm{sec}$. Temperature of sea water, $20^{\circ} \mathrm{C} . \mathrm{w}_{1}$, $\mathrm{w}_{2}$. Myctophum punctatum. Flashing of photophores induced by mechanical stimulation of intact living fish. Time scale, $\mathrm{I} / \mathrm{sec}$. Water temperature, $\mathrm{I}^{\circ} \mathrm{C} . \mathrm{x}_{1}, \mathrm{x}_{2}$. Searsia koefoedi. Records of the glow produced when a fish discharges a luminous secretion into sea water. Tactile stimulus. Time scale, $\mathrm{I} / \mathrm{sec}$. Water temperature $12-15^{\circ} \mathrm{C}$. 
TABLE 3. INTENSITY OF LUMINESCENCE OF SOME PELAGIC ANIMALS

Radiant flux, $\mu \mathrm{W}$ or $\mu \mathrm{J} / \mathrm{cm}^{2}$ receptor surface

\begin{tabular}{|c|c|c|c|c|c|}
\hline Group and species & $\begin{array}{l}\text { Measured } \\
\text { Flux }\end{array}$ & $\begin{array}{l}\text { Recording } \\
\text { distance } \\
(\mathrm{cm})\end{array}$ & $\overbrace{\text { Flux at I m distance in air }}^{\text {Recalculated }}$ & $\underset{\left({ }^{\circ} \mathrm{C}\right)}{\text { Temp. }}$ & Source \\
\hline $\left.\begin{array}{l}\text { Radiolaria } \\
\text { Cytocladus major and } \\
\text { Aulosphaera triodon }\end{array}\right\}$ & $\begin{array}{l}0.2 \times 1 \mathrm{I}^{-6} \mu \mathrm{W} \\
\mathrm{I} \cdot 7 \times 1 \mathrm{O}^{-6} \mu \mathrm{W}\end{array}$ & $\begin{array}{l}5 \cdot 6 \\
5 \cdot 6\end{array}$ & $\begin{array}{l}0.6 \times 10^{-9} \mu \mathrm{W} \\
5.3 \times 10^{-9} \mu \mathrm{W}\end{array}$ & $\begin{array}{l}22 \\
22\end{array}$ & $\begin{array}{l}\text { Original } \\
\text { Original }\end{array}$ \\
\hline $\begin{array}{l}\text { Hydromedusae } \\
\text { Colobonema sericeum } \\
\text { Crossota alba } \\
\text { Aeginura grimaldii }\end{array}$ & $\begin{array}{l}0.8 \times 10^{-6} \mu \mathrm{W} \\
\mathrm{I} \cdot 0 \times \mathrm{IO}^{-6} \mu \mathrm{W} \\
0.02 \times 10^{-6} \mu \mathrm{W} \\
0.5 \times 10^{-6} \mu \mathrm{W}\end{array}$ & $\begin{array}{l}9 \cdot 7 \\
9 \cdot 7 \\
\text { I3 } \\
\text { I4 }\end{array}$ & $\begin{array}{l}7.2 \times 10^{-9} \mu \mathrm{W} \\
9.5 \times 10^{-9} \mu \mathrm{W} \\
0.4 \times 10^{-9} \mu \mathrm{W} \\
9.3 \times 10^{-9} \mu \mathrm{W}\end{array}$ & $\begin{array}{r}8 \\
8 \\
\text { I3 } \\
\text { II }\end{array}$ & $\begin{array}{l}\text { Original } \\
\text { Original } \\
\text { Original } \\
\text { Original }\end{array}$ \\
\hline $\begin{array}{l}\text { Siphonophora } \\
\text { Vogtia spinosa } \\
\text { V. glabra } \\
\text { Rosacea plicata } \\
\text { Hippopodius hippopus }\end{array}$ & $\begin{aligned} 0.7 & \times 10^{-6} \mu \mathrm{W} \\
10.6 & \times 10^{-6} \mu \mathrm{W} \\
19.4 & \times 10^{-6} \mu \mathrm{W} \\
0.6 & \times 10^{-6} \mu \mathrm{W} \\
1.2 & \times 10^{-6} \mu \mathrm{W} \\
0.4 & \times 10^{-6} \mu \mathrm{W} \\
0.7 & \times 10^{-6} \mu \mathrm{W}\end{aligned}$ & $\begin{array}{l}\text { I4 } \\
\text { I7·4 } \\
7 \cdot 8 \\
7 \\
\text { I0·7 } \\
8 \\
7 \cdot 7\end{array}$ & $\begin{aligned} 13.7 & \times 10^{-9} \mu \mathrm{W} \\
320.9 & \times 10^{-9} \mu \mathrm{W} \\
120 & \times 10^{-9} \mu \mathrm{W} \\
2.4 & \times 10^{-9} \mu \mathrm{W} \\
13.7 & \times 10^{-9} \mu \mathrm{W} \\
2.6 & \times 10^{-9} \mu \mathrm{W} \\
4.2 & \times 10^{-9} \mu \mathrm{W}\end{aligned}$ & $\begin{array}{c}8 \\
21 \cdot 8 \\
8 \\
20 \\
20 \\
22 \\
22\end{array}$ & $\begin{array}{l}\text { Original } \\
\text { Original } \\
\text { Original } \\
\text { Original } \\
\text { Original } \\
\text { Original } \\
\text { Original }\end{array}$ \\
\hline $\begin{array}{l}\text { Scyphomedusae } \\
\text { Atolla wyvillei }\end{array}$ & $\begin{aligned} 0.1 & \times 10^{-6} \mu \mathrm{W} \\
10.2 & \times 10^{-6} \mu \mathrm{W}\end{aligned}$ & $\begin{array}{l}5 \cdot 7 \\
14\end{array}$ & $\begin{array}{r}0.3 \times 10^{-9} \mu \mathrm{W} \\
199.9 \times 10^{-9} \mu \mathrm{W}\end{array}$ & $\begin{array}{l}24 \\
13\end{array}$ & $\begin{array}{l}\text { Original } \\
\text { Original }\end{array}$ \\
\hline $\begin{array}{l}\text { Ctenophora } \\
\text { Beroë ovata } \\
\text { Mnemiopsis leidyi }\end{array}$ & $\begin{aligned} & 0.89 \times 10^{-6} \mu \mathrm{J} \\
& 118 \times 10^{-6} \mu \mathrm{W} \\
& 0.5 \times 10^{-4} \mu \mathrm{W} \\
&>0.75 \times 10^{-4} \mu \mathrm{W}\end{aligned}$ & $\begin{array}{l}13 \cdot 8 \\
26 \cdot 9 \\
50 \\
50\end{array}$ & $\begin{aligned} \mathrm{I} 6.95 & \times 10^{-9} \mu \mathrm{W} \\
8538.5 & \times 10^{-9} \mu \mathrm{W} \\
12,500 & \times 10^{-9} \mu \mathrm{W} \\
18,750 & \times 10^{-9} \mu \mathrm{W}\end{aligned}$ & $\begin{array}{l}24 \\
24 \cdot 5 \\
- \\
-\end{array}$ & $\begin{array}{l}\text { Original } \\
\text { Original } \\
\text { Clarke \& Backus, I956 } \\
\text { Clarke \& Backus, I956 }\end{array}$ \\
\hline $\begin{array}{l}\text { Crustacea } \\
\text { Acanthephyra purpurea } \\
\text { Euphausia pacifica }\end{array}$ & $\begin{array}{c}0.23 \times 10^{-6} \mu \mathrm{W} \\
\mathrm{I} \cdot 0 \mathrm{I} \times 10^{-6} \mu \mathrm{W} \\
\mathrm{I} \cdot 6 \times 10^{-3}-2 \times 10^{-3} \mu \mathrm{W}\end{array}$ & $\begin{array}{l}9 \\
9 \\
1\end{array}$ & $\begin{array}{c}\mathrm{I} \cdot 9 \times 10^{-9} \mu \mathrm{W} \\
8 \cdot 2 \times 10^{-9} \mu \mathrm{W} \\
\mathrm{I} 60 \times 10^{-9}-200 \times 10^{-9} \mu \mathrm{W}\end{array}$ & $\begin{array}{r}9 \\
9 \\
-\end{array}$ & $\begin{array}{l}\text { Original } \\
\text { Original } \\
\text { Kampa \& Boden, I957 }\end{array}$ \\
\hline $\begin{array}{l}\text { Tunicata } \\
\text { Pyrosoma atlanticum }\end{array}$ & $\begin{array}{c}\mathrm{I} \cdot \mathrm{I} 8 \times \mathrm{IO}^{-6} \mu \mathrm{W} \\
\mathrm{I} 7 \times 10^{-6} \mu \mathrm{W} \\
8 \times \mathrm{IO}^{-3}-4 \times \mathrm{IO}^{-2} \mu \mathrm{W}\end{array}$ & $\begin{array}{l}10 \cdot 8 \\
28 \cdot 3 \\
I\end{array}$ & $\begin{array}{c}13.8 \times 10^{-9} \mu \mathrm{W} \\
136 \mathrm{I} \cdot 5 \times 10^{-9} \mu \mathrm{W} \\
800 \times \mathrm{IO}^{-9}-4000 \times \mathrm{IO}^{-9} \mu \mathrm{W}\end{array}$ & $\begin{array}{l}14 \\
23 \\
\end{array}$ & $\begin{array}{l}\text { Original } \\
\text { Original } \\
\text { Kampa \& Boden, I957 }\end{array}$ \\
\hline $\begin{array}{l}\text { Teleostei } \\
\text { Searsia schnakenbecki }\end{array}$ & $\begin{array}{l}\times 10^{-6} \mu \mathrm{W} \\
\times 10^{-6} \mu \mathrm{W}\end{array}$ & $\begin{array}{l}9 \\
9\end{array}$ & $\begin{array}{ll}150 & \times 10^{-9} \mu \mathrm{W} \\
430 & \times 10^{-9} \mu \mathrm{W}\end{array}$ & $\begin{array}{l}\text { II } \\
\text { II }\end{array}$ & $\begin{array}{l}\text { Original } \\
\text { Original }\end{array}$ \\
\hline S. koefoedi & $\begin{aligned} 98 & \times 10^{-6} \mu \mathrm{W} \\
130 & \times 10^{-6} \mu \mathrm{W}\end{aligned}$ & $\begin{array}{l}14.7 \\
14.7\end{array}$ & $\begin{array}{ll}2117 & \times 10^{-9} \mu \mathrm{W} \\
2808 & \times 10^{-9} \mu \mathrm{W}\end{array}$ & $\begin{array}{l}\text { I2-I5 } \\
\text { 12-I5 }\end{array}$ & $\begin{array}{l}\text { Original } \\
\text { Original }\end{array}$ \\
\hline Myctophum punctatum & $\begin{array}{l}0 . \mathrm{I} \times 10^{-6} \mu \mathrm{J} \\
5.8 \times 10^{-6} \mu \mathrm{W}\end{array}$ & $\begin{array}{l}9.5 \\
9.5\end{array}$ & $\begin{array}{r}0.925 \times 10^{-9} \mu \mathrm{J} \\
52.345 \times 10^{-9} \mu \mathrm{W}\end{array}$ & $\begin{array}{l}\text { 16 } \\
\text { 16 }\end{array}$ & $\begin{array}{l}\text { Original } \\
\text { Original }\end{array}$ \\
\hline
\end{tabular}


receptor surface (Table 2). By assuming that the light intensity falls off with distance according to the inverse square law, values can be calculated for light intensities at a standard distance of $\mathrm{I} \mathrm{m} \mathrm{in} \mathrm{air,} \mathrm{viz.} 0.55 \times 10^{-9}$ to $5.34 \times 10^{-9} \mu \mathrm{W} / \mathrm{cm}^{2}$ receptor surface (Table 3 ). Deviation from the inverse square law, owing to size of the source, decreases with distance. In the present instance, the error from this factor is small, and the flux calculated at I $\mathrm{m}$ may be considered a minimal estimate. The luminescence of these radiolarians appeared somewhat diffuse. If they were uniformly diffusing spheres, the total radiant flux from the entire surface of the animals would range from $0.69 \times \mathrm{IO}^{-4}$ to $6.7 \mathrm{I} \times \mathrm{IO}^{-4} \mu \mathrm{W} / 4 \pi$ steradians.

No spectral emission curve is available for the light of radiolarians, and in the above calculations I have employed the spectral curve for Chaetopterus light as a substitute.
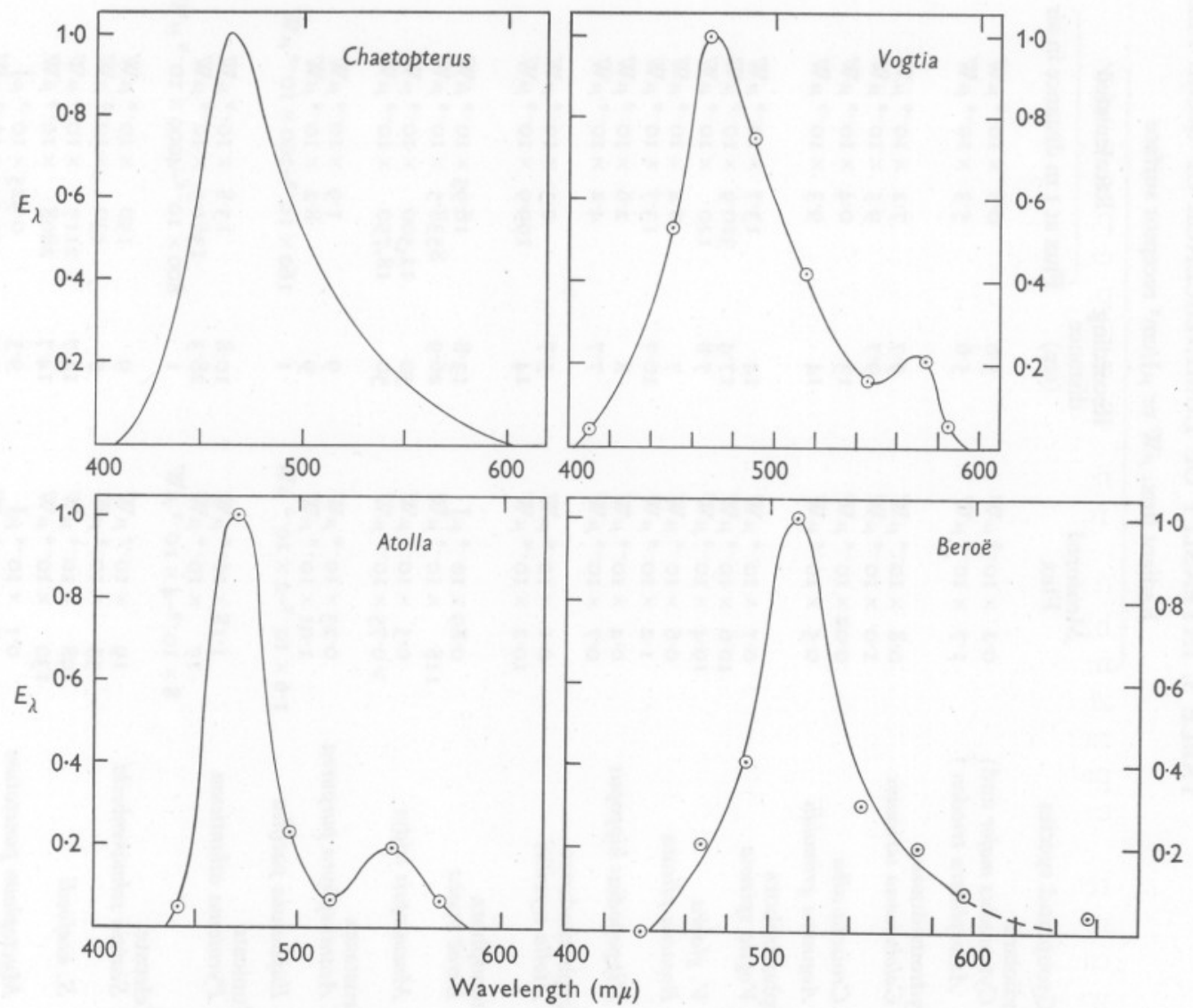

Text-fig. 4. Relative spectral emission curves for the light of four marine animals, namely, Chaetopterus variopedatus, Vogtia glabra, Atolla wyvillei and Beroë ovata. 
Chaetopterus light is blue, and has a peak at about $465 \mathrm{~m} \mu$ (Text-fig. 4) (Nicol, I957c). Since the response curve of the photomultiplier is fairly flat below $500 \mathrm{~m} \mu$ (Nicol, I958a, fig. $2 \mathrm{~A}$ ), a difference of Io or $20 \mathrm{~m} \mu$ in the maximum of the spectral emission curve used in making the calculations would result in only a small change in estimated flux. I have calculated radiant flux on the basis of a spectral emission curve resembling that in Text-fig. 4, but displaced $20 \mathrm{~m} \mu$ towards longer wavelengths; the result for the first response given in Table 2 is $2.02 \times \mathrm{IO}^{-6} \mu \mathrm{W} / \mathrm{cm}^{2}$ receptor surface at $5.6 \mathrm{~cm}$ in air. This differs from the response given in the table $\left(\mathrm{I} \cdot 70 \times 10^{-6} \mu \mathrm{W}\right)$ by $19 \%$.

Cytocladus is widespread in the Atlantic and $C$. major has been found previously in a catch from $3000 \mathrm{~m}$ (Schröder, 1907). Aulosphaera triodon appears to be cosmopolitan (Haecker, 1907).

\section{HYDROMEDUSAE}

Crossota alba Bigelow. A single specimen was collected ('Discovery' Sta. no. 3376). The jellyfish was bell-shaped, and about $24 \mathrm{~mm}$ in diameter. When mechanically stimulated it gave a very weak bluish glow lasting about I sec. It soon fatigued, for a second and further stimuli evoked much weaker responses. The spectral emission curve for Atolla luminescence (see p. 7I8) was used to calculate radiant flux. A. wyvillei also emits a blue light, extending from about $4 \mathrm{IO}$ to $600 \mathrm{~m} \mu$, with a peak at $470 \mathrm{~m} \mu$ (Text-fig. 4, p. 714). According to Harvey (1952), the light of two other Hydromedusae (Aequorea and Mitrocoma), examined with a hand spectroscope, extends from about 460 to $600 \mathrm{~m} \mu$. At I $\mathrm{m}$ in air, estimated radiant flux for Crossota alba is $0.4 \times 10^{-9} \mu \mathrm{W} / \mathrm{cm}^{2}$ receptor surface.

This is the first report of luminescence in C. alba. It is a deep-water jellyfish known previously from the North Pacific and tropical Atlantic (Kramp, 1947, I957).

Aeginura grimaldii Maas. Two specimens of this jellyfish were examined ('Discovery' Sta. no. 3376). With light mechanical stimulation they emitted a bluish glow lasting I-4 sec (Text-fig. 3D). An estimate of light intensity was made, the calculation being based on the relative spectral emission curve for Atolla light (Text-fig. 4). At a distance of I m (in air), minimal estimated radiant flux is $9.3 \times 10^{-9} \mu \mathrm{W} / \mathrm{cm}^{2}$ receptor surface. A. grimaldii is a bathypelagic species of world-wide distribution (Russell, I953), in which luminescence has not previously been reported.

Octophialucium funeraria (Quoy \& Gaimard). This is a deep-sea medusa, reaching a diameter of about $4 \mathrm{~cm}$. One specimen was examined ('Sarsia' Sta. no. I, cruise $6 / 55$ ). When mechanically stimulated by gently stroking it with a camel-hair brush, it emitted a bluish glow. No measurement of light intensity was made. Its luminescence is here noted, since it seems not to have been previously reported. O. funeraria has been found at various stations in the Atlantic and Mediterranean. 
Colobonema sericeum Vanhöffen. One specimen was examined ('Sarsia' Sta. no. 5, cruise 3/57). This medusa is bell-shaped, up to $4 \mathrm{~cm}$ in diameter and height. It is a deep-water species, found in temperate and warm regions of the Atlantic, Pacific and Indian Oceans (Russell, I953). When mechanically stimulated, the specimen of $C$. sericeum emitted a blue glow, lasting about $2 \sec$ (Text-fig. 3E, F). A spectral emission curve was not obtained, and that for Atolla (Text-fig. 4) was used in calculating light intensity. At a distance of I m (in air), estimated radiant flux would be $7 \times \mathrm{IO}^{-9}$ to $9 \times \mathrm{IO}^{-9} \mu \mathrm{W} / \mathrm{cm}^{2}$ receptor surface. This appears to be the first report of luminescence in Colobonema sericeum.

Other luminescent species of Hydromedusae are noted by Russell (1953). Certain physiological and histological observations on luminescence and photogenic tissue of Aequorea have been presented by Davenport and Nicol (1955).

\section{SIPHONOPHORA}

Vogtia spinosa Keferstein \& Ehlers. Specimens were obtained from 'Discovery' Sta. nos. 3374 and 3376 . When examined in the dark, fragments of this species were found to be markedly luminescent. Light, evoked by mechanical stimulation, appeared as a bluish glow diffused through the fragment (nectophores or gastrozooids). The specimens appeared very sensitive to mechanical stimuli, and responded by glowing to roll of the ship, and slight tapping of the vessel in which they lay. Luminescence was not inhibited by exposure to light ( $60 \mathrm{~W}$ tungsten lamp at about $\mathrm{I} \mathrm{m}$ ). The glow lasts from 2 to II sec, depending on the strength of stimulus (Text-fig. $3 \mathrm{G}, \mathrm{H}$ ). To calculate light intensity, a spectral emission curve obtained for $V$. glabra was used (Text-fig. 4). At I m (in air), minimal estimates of radiant flux range from $\mathrm{I} 4 \times \mathrm{IO}^{-9}$ to $32 \mathrm{I} \times \mathrm{IO}^{-9} \mu \mathrm{W} / \mathrm{cm}^{2}$ receptor surface. This appears to be the first report of luminescence in $V$.spinosa, which is a widely distributed bathypelagic species known from the Atlantic, Pacific, and Mediterranean (Bigelow \& Sears, 1937).

V. glabra Bigelow. A fragmented specimen was obtained ('Sarsia' Sta.no. 2I, cruise 3/57). Fragments emitted a bluish luminescence under mechanical stimulation. The glow lasted some $4 \mathrm{sec}$ (Text-fig. 3J). An approximate spectral emission curve was obtained with the aid of Disc II. This was spun at speeds of $\mathrm{I}-2 \mathrm{rev} . / \mathrm{sec}$. The specimen was positioned close beneath the disc, and luminescence was evoked by gentle tactile stimulation (Text-fig. 5). Water temperature was $8^{\circ} \mathrm{C}$. Spectral emission extends from about 430 to $590 \mathrm{~m} \mu$, with a maximum at about $470 \mathrm{~m} \mu$ (Text-fig. 4). A single measurement of light intensity afforded an estimate of $120 \times 10^{-9} \mu \mathrm{W} / \mathrm{cm}^{2}$ at $\mathrm{I} \mathrm{m}$ (in air) (Table 3). V. glabra is a bathypelagic species, found in the Mediterranean and the Atlantic (Leloup, 1955), and known to be luminescent (see Totton, 1954).

Rosacea plicata Bigelow. Fragments of a specimen were obtained ('Discovery' 
Sta. no 3374). Luminescence was evoked by mechanical stimulation. The light had a blue hue, and the responses lasted $\mathrm{I}-2 \mathrm{sec}$ (Text-fig. $3 \mathrm{~K}, \mathrm{~L}$ ). The spectral emission curve of $V$. glabra (Text-fig. 4) was used in calculating light intensity. At I m (in air), estimated radiant flux is $2.4 \times \mathrm{IO}^{-9}$ to $13.7 \times 10^{-9} \mu \mathrm{W} / \mathrm{cm}^{2}$ receptor surface (Table 3$)$. $R$. plicata has a world-wide distribution. Although usually obtained in catches from deeper waters, it has occasionally been found at the surface (Bigelow \& Sears, 1937; Leloup, 1955).

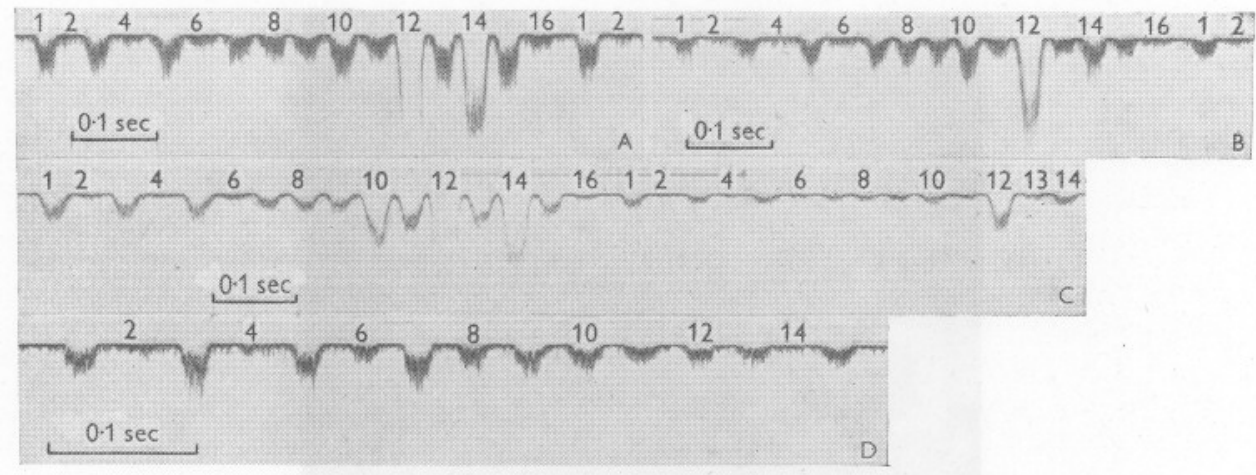

Text-fig. 5. A, B. Oscilloscope deflexions obtained when Disc II was used to analyse the light of Vogtia glabra. Time scale, 0.1 sec. Filters in order: 1,$604 ; 2, \mathrm{OX}_{1} ; 3,604 ; 4,607 ; 5,604$; 6,$606 ; 7,604,8,605 ; 9,604 ; 10,603 ; 11,604 ; 12,602 ; 13,604 ; 14,601 ; 15,604 ;$ I6, OV I. Temperature of sea water $8^{\circ} \mathrm{C}$. Disc speed, ca. I.7 rev./sec. C. Analysis of the light of Atolla wyvillei with Disc II. Numbering of filters as in A and B. Water temperature $20^{\circ} \mathrm{C}$. Speed of rotation about I.7 rev./sec. Time, 0.I sec. D. Analysis of the light of Beroë ovata with Disc I. Filters in order: 1,$603 ; 2,608 ; 3,603 ; 4,607 ; 5,603 ; 6,606 ; 7,603$; 8,$605 ; 9,603 ; 10,604 ;$ I I , 603; I2, 602; I3, 603; I4, 60I; I5, 603. Temperature of sea water, about $19^{\circ} \mathrm{C}$. Disc speed about $\mathrm{I}$ rev. $/ \mathrm{sec}$.

Hippopodius hippopus (Forskål). Fragments of a specimen were obtained ('Discovery' Sta. no. 3369). When mechanically stimulated the animal emitted a blue light lasting $\mathrm{I}-2 \sec ($ Text-fig. $3 \mathrm{M}, \mathrm{N}$ ). The spectral emission curve for the light of Vogtia glabra (Text-fig. 4) was used for calculating radiant flux. At I m (in air), estimated flux was $2.6 \times \mathrm{IO}^{-9}$ to $4 \cdot 2 \times 1 \mathrm{IO}^{-9} \mu \mathrm{W} / \mathrm{cm}^{2}$ receptor surface. There are previous reports of luminescence in this species (Dubois, 19I4; Totton, 1954). Hoppopodius hippopus occurs in the Mediterranean and in warmer regions of the three oceans (Totton, 1954; Leloup, 1955).

\section{SCYPHOMEDUSAE}

Atolla wyvillei Haeckel. Many specimens were examined from stations as follows: 'Discovery' Sta. nos. 3366, 3368, 3372, 3374, 3375 and 3376 ; 'Sarsia' Sta. no. 21 , cruise $3 / 57$. These jellyfish are umbrella-shaped, ranging up to I5 $\mathrm{cm}$ in diameter. When mechanically stimulated, some specimens emitted a faint bluish light all around the margin; some emitted only a weak point of 
light in the immediate vicinity of stimulation; still others remained dark. These differences in behaviour possibly depend upon the condition of the specimen, amount of buffeting it has received in the net, etc. Luminescence has not hitherto been reported in this species.

Light appears as a brief flash or glow, lasting up to $2 \sec$ (Text-fig. $3 \mathrm{O}, \mathrm{P}$ ). Relative spectral composition of the light was determined by means of recording Disc II (Text-fig. 5C). The light is blue in colour, and emission occurs

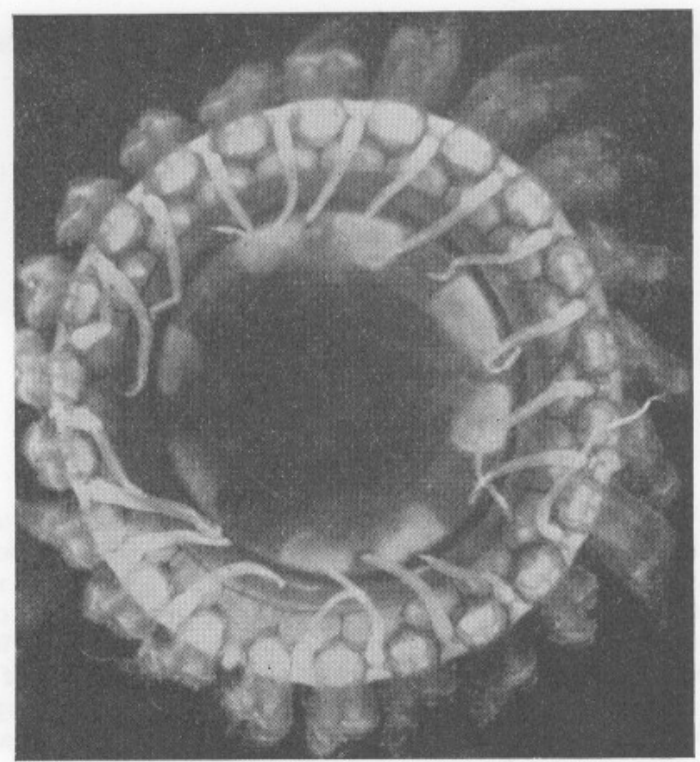

Text-fig. 6. Dorsal view of Atolla wyvillei. From a colour transparency of a living animal.

at about $470 \mathrm{~m} \mu$, with hint of a secondary peak at about $570 \mathrm{~m} \mu$. Calculated values of light intensity are given in Tables 2 and 3. At a distance of $\mathrm{I} \mathrm{m}$ (in air), minimal estimates of the intensity of Atolla luminescence range up to $200 \times \mathrm{IO}^{-9} \mu \mathrm{W} / \mathrm{cm}^{2}$ receptor surface.

When a specimen of $A$. wyville $i$ was subjected to carefully localized mechanical stimulation with a probe, the light appeared in a thin streak just inside the peripheral edge of the thick coronal muscle, at the base of the rhopalar peduncle, between two tentacles (Text-fig. 6). It was visible from the upper surface, but not from the lower surface of the jellyfish. The thick coronal muscle of Atolla is opaque and white. The photogenic tissue must be above this muscle layer, which prevents the light from shining through to the lower surface. The white muscle band may also act as a reflector for the luminescence.

The white opacity of the coronal muscle extends throughout the thickness 
of the latter. The white appearance is not destroyed by the following agents: water, formalin, ethanol, ether, I and 10 $\%$ acetic acid, I $\% \mathrm{HCl}, 10 \% \mathrm{NH}_{3}$, and $0 . \mathrm{I} \% \mathrm{NaOH}$. These negative results rule out the possibility that the white appearance is due to some deposit of purine material such as guanine, pterine, or even uric acid. It is probably a characteristic of the physical structure of the muscle or its contained connective tissue.

Histological sections were cut from the edge of the umbrella to search for luminescent tissue. The material was fixed in formalin, and post-fixed in Wittmaack's solution. Sections were cut in celloidin, and stained with Weigert's haematoxylin, Bordeaux red and aniline blue. A patch of tall columnar epithelial cells occurs in the floor of the rhopalar canal, and in its connexion with the canal running along the lateral wall of the rhopalar pedalium, opposite the nematocyst cushion. These columnar cells constitute a modified endodermal lining, which elsewhere in the canal consists of cuboidal cells. They have a very glandular appearance. The nucleus is almost central; the basal half of the cell is vacuolar, whereas the distal half is packed with small granules. The latter are stained mostly blue (with aniline blue), but some larger granules have taken up the Bordeaux red preferentially. Near the distal margin of each cell is a small spherical clear area, appearing like a lenticular organelle. Cellular dimensions are: height, about $45 \mu$; width, I2 $\mu$; peripheral clear area, about $9 \mu$ in diameter. The position and glandular character of these cells suggest that they may represent the luminous tissue.

A. wyvillei is a bathypelagic species having a cosmopolitan distribution (Kramp, 1947).

Among the specimens of Atolla in which luminescence was observed was one of $A$. parva, the new species recently described by Russell (1958).

Periphylla periphylla (Péron \& Lesueur). Two specimens of this jellyfish were examined and were found to be luminescent ('Sarsia' Sta. no. I, cruise $6 / 55$ ). When mechanically stimulated they emitted a blue glow around the margin, either in the tentacles, or in the rim of the umbrella. The light was not recorded. There appears to be no previous notice of its luminescence. $P$. periphylla is bathypelagic and has a world-wide distribution (Kramp, 1947).

\section{CTENOPHORA}

Beroë ovata Bosc. (=B. cucumis Fabricius). Specimens were examined from 'Discovery' Sta. nos. 3366, 3368 and 3376; and from 'Sarsia' Sta. no. 5, cruise 3/57. The light of Beroë appears green to the eye (cf. Harvey, 1955). A few records, obtained with Disc I, gave enough data to make an approximate estimation of spectral composition (Text-fig. 5D). A strip of the animal, containing several combs, was pinned out in a black dish underneath the disc, and light was evoked by stimulating the preparation with a camel-hair brush. On analysing the results, it appears that light emission extends from about 440 to $650 \mathrm{~m} \mu$, with a peak around 5 IO $\mathrm{m} \mu$ (Text-fig. 4, p. 714). 
The relative spectral composition curve, shown in Text-fig. 4, was used to calculate light intensities. At a distance of $\mathrm{I} \mathrm{m}$ (in air), estimated radiant flux is $\mathrm{I} \cdot 7 \times \mathrm{IO}^{-8}$ to $8.5 \times 1 \mathrm{IO}^{-6} \mu \mathrm{W} / \mathrm{cm}^{2}$ receptor surface (Tables 2 and 3 ). Clarke \& Backus (1956), using a different method, have measured the intensity of light emitted by the ctenophore Mnemiopsis leidyi. At $50 \mathrm{~cm}$ distance, radiant fluxes were $0.5 \times 10^{-4}$ and at least $0.75 \times 10^{-4} \mu \mathrm{W} / \mathrm{cm}^{2}$ receptor surface (two determinations). When calculated for a distance of $\mathrm{I} \mathrm{m}$ (in air), the equivalent intensities are $0.1 \times 10^{-4}$ and $>0.2 \times 10^{-4} \mu \mathrm{W} / \mathrm{cm}^{2}$ (Table 3).

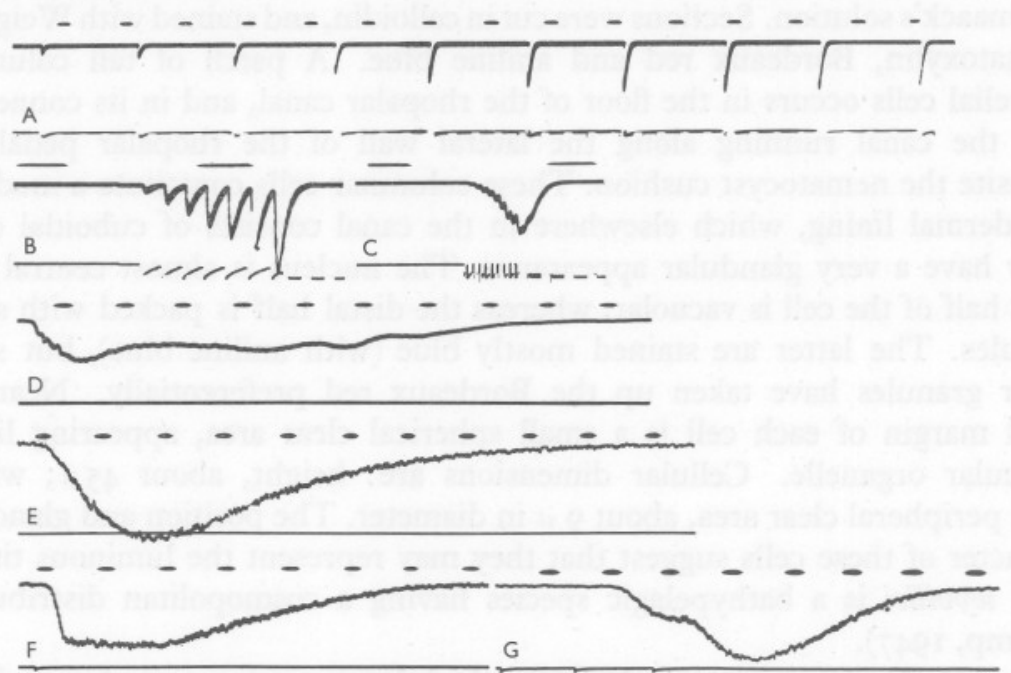

Text-fig. 7. A, B, C. Flashes of Beroë ovata under electrical stimulation. Point responses. Stimuli intervals: A, I. $24 \mathrm{sec}$; B, O.II sec; c, $0.029 \mathrm{sec}$. Time scale above, I/sec. Stimuli on lower line. Water temperature $20-2 \mathrm{I}^{\circ} \mathrm{C}$. D-G. Responses of Pyrosoma atlanticum to tactile and mechanical stimuli. D. Tactile stimulation. Local response and transmitted waves. Specimen $10 \mathrm{~cm}$. long. Time scale, $0.98 \mathrm{sec}$. Water temperature $25^{\circ} \mathrm{C}$. E. Local response to tactile stimulus. Time scale, $0.96 \mathrm{sec}$. Water temperature $25^{\circ} \mathrm{C}$. F. Local response to an electric shock (shown on lower line). Water temperature $25^{\circ} \mathrm{C}$. Time, $0.96 \mathrm{sec}$. G. Responses to burst of shocks at $\mathrm{I} / \mathrm{sec}$. Water temperature, $24^{\circ} \mathrm{C}$. Time, $\mathrm{I} / \mathrm{sec}$. A low-pass filter was used when recording traces $D-G$ to reduce noise.

When Beroë is mechanically stimulated, waves of luminescence run along the meridional combs. The conducting system is non-polarized, since transmission occurs with facility in either direction (Panceri, 1872). The same responses occur in Mnemiopsis (see Moore, 1924). The light appears in two closely spaced thin green lines along each of the combs, seemingly associated with paired strips of luminous tissue in the walls of the meridional canals (see Harvey, 1952). Under strong mechanical stimulation, the light has a flickering character, owing to repetitive flashing occurring along the length of the comb, such flashes continuing when stimulation has ceased. Multiple or repetitive flashing occurs also in Beroë under electrical stimulation (Nicol, 1955a), and it has been observed likewise in Mnemiopsis (see Chang, 1954). 
The luminescence of ctenophores is inhibited by light, and specimens of Beroë were dark-adapted before use. Pieces containing one or several combs were pinned out on wax and were covered with sea water. Electrical stimuli were delivered through wire electrodes placed on the combs.

With local responses, i.e. those confined to the immediate vicinity of the electrodes, it is found that each shock above threshold produces a flash (Text-fig. 7A). With repetitive stimulation, the consecutive flashes increase progressively in intensity for some time (perhaps 8-I2 flashes), and then reach maximum or plateau level, after which decline sets in. The increment of consecutive flashes is best seen when stimulation is at a rate slow enough for each response-record to return to base line, and for no summation of the light of successive flashes (Text-fig. 7A). In records of transmitted waves of light, obtained from long lengths of comb, the intensity relationships of single flashes are obscured by repetitive responses. At fast rates of stimulation (9/sec or more), the individual flashes tend to fuse together but they can still be distinguished at frequencies of $34 / \mathrm{sec}$ (Text-fig. $7 \mathrm{~B}, \mathrm{C}$ ).

Under repetitive stimulation, augmentation of intensity can be produced by two factors, summation of light when the flashes recur at brief intervals, less than the duration of a single flash, and facilitation occasioned by build-up of an excitatory state such that one pulse leaves a residual condition enhancing second and later responses. Although the effect is somewhat irregular, there is a tendency for facilitatory increment to be greater at faster rates of stimulation (or shorter intervals), as shown in Text-fig. 8. The effect was also brought out as follows. Paired pulses were given at selected intervals and the responses measured. The ratios of the second to the first flash were:

$\begin{array}{cc}\begin{array}{c}\text { Interval between } \\ \text { flashes (sec) }\end{array} & \begin{array}{c}\text { Ratio of intensity of } \\ \text { second to first flash }\end{array} \\ \mathrm{I} 20 & \mathrm{I} \cdot 3 \\ 60 & \mathrm{I} \cdot 2 \\ \mathrm{I} 2 & \mathrm{I} \cdot 4 \\ 4 & 2 \\ \mathrm{I} \cdot 68 & 2 \\ \mathrm{I} \cdot 24 & \mathrm{I} \cdot 8 \\ 0.62 & \mathrm{I} \cdot 8 \\ 0.24 & 2 \\ 0 . \mathrm{II} & 2 \cdot 7\end{array}$

Some residual facilitation is still detectable $2 \mathrm{~min}$ after a previous pulse. A similar increment of facilitation with rise in frequency appears to hold in Mnemiopsis (see Chang, 1954, p. 382, fig. 9). Continued stimulation leads to falling off in intensity, i.e. to fatigue. This becomes apparent after Io or so pulses. A single flash, from a point area, has a duration of about $0.16 \mathrm{sec}$ $\left(20-2 \mathrm{I}^{\circ} \mathrm{C}\right)$. Latent period is about $20 \mathrm{msec}$.

The progressive increase in intensity of consecutive flashes, shown in Textfig. $7 \mathrm{~A}$, is one more manifestation of neuro-effector facilitation, so well documented in muscular responses of sea anemones and other coelenterates 
(Pantin, 1952). It has also been detected in the luminous responses of hydromedusans and pennatulids (Davenport \& Nicol, 1955; Nicol, 1955b). It is not known where the facilitatory process occurs in ctenophores, but there is evidence in polynoids that it can occur within the photocytes or lightgenerating cells (Nicol, 1957a).

Beroë ovata is a cosmopolitan form, found usually in upper waters (Chun, I880; Bigelow, I912; Mayer, 1912; Mortensen, I912; Krumbach, I927; Sears, 1954).

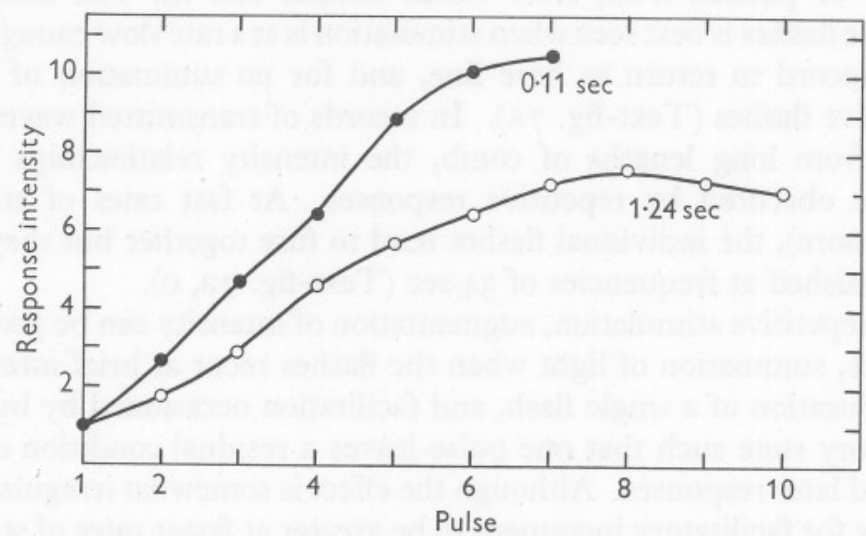

Text-fig. 8. Facilitatory increment in consecutive flashes of Beroe ovata at two frequencies (intervals shown). Ordinates show relative intensities. Temp. $20-2 \mathrm{I}^{\circ} \mathrm{C}$.

\section{CRUSTACEA DECAPODA}

Acanthephyra purpurea M.-Edw. Luminescence was observed in a deepsea shrimp belonging to this species ('Sarsia' Sta. no. 5, cruise 3/57). This specimen appears to be $A$. purpurea sensu stricto, since it has only four pairs of dorso-lateral spines on the telson, and no tooth on the dorsal carina of the fourth abdominal segment (Kemp, 1939). A. purpurea is a widely distributed bathypelagic shrimp found in the Atlantic, south of $50^{\circ} \mathrm{N}$., in the Pacific and in the Indian Oceans (Kemp, 1910, 1939; Stephenson, 1923; Balss, 1925).

Examined in the laboratory in darkness, Acanthephyra was found to discharge a luminous secretion from the head region into the surrounding sea water when the animal was excited mechanically. The light had a blue colour, and the discharge continued to glow for I-5 sec (Text-fig. $3 \mathrm{~S}, \mathrm{~T}$ ). Luminescence was soon exhausted under repeated stimulation, and it was not possible to determine spectral composition.

Since the light of $A$. purpurea has a bluish colour, I have used the relative spectral emission curve of Cypridina light, as determined by Coblentz \& Hughes (1926), for calculating light intensity. C. hilgendorfii also discharges a luminous secretion and its light is blue in colour, with maximal emission at 
about $480 \mathrm{~m} \mu$ (Text-fig. I9A). The intensity of the discharge ranged from $2 \times \mathrm{IO}^{-9}$ to $8 \times \mathrm{IO}^{-9} \mu \mathrm{W} / \mathrm{cm}^{2}$ receptor surface at a distance of $\mathrm{I} \mathrm{m}$ (in air).

The discharge of a luminous secretion from the antennal glands or head glands of various other species has been observed repeatedly, e.g. in Heterocarpus alphonsi, Plesiopennaeus (=Aristaeus) coruscans, Hoplophorus novaezealandiae, H. spinicauda and Systellaspis debilis. The last-named is a species that also possesses integumentary photophores (Alcock, 1902; Dahlgren, I916; Chace, I940; Dennell, I940, I955; Harvey, I952.)

TUNICATA

Pyrosoma. Specimens for observation and histology were collected as follows. P. atlanticum Péron-'Discovery' Sta. nos. 3344, 3354, 3355, 3365, 3366, 3374 and 3375; 'Sarsia' Sta. no. 23, cruise 3/57; one specimen from deep water off San Diego, California, I2 December 1953. P. spinosum Herdman-'Sarsia' Sta. no. I, cruise 6/55.

Pyrosoma is one of the most brightly luminescent animals of the open ocean. Its light emission was first noted by Péron in 1804, and has been commented upon repeatedly-see descriptions by Bennett (I840), Huxley (I851), Moseley (I892), and Steuer (I910); and reviews of the literature by Neumann (1934), and Harvey (1952).

Pyrosoma is a colonial animal and light is emitted by each of the zooids. During a normal response an excited colony appears aglow from numerous points of blue light. Before presenting some original observations I would point out that the luminescence of Pyrosoma shows a combination of peculiarities not found in other animals. First there is a general agreement that the light of Pyrosoma is intermittent. Secondly, the light is transmitted as a wave along the colony, although nervous connexions between the zooids still await discovery. Thirdly, luminescence is evoked by illumination. Fourthly, the light is ascribed to luminescent symbiotic bacteria. This belief, fostered by Buchner (I9I4) and Pierantoni (I92I), now appears to be generally accepted (Brien, I948; Young, I950; Caullery, I952). Other luminescent bacteria, however, emit light continuously (discussion in Harvey, 1952).

Pyrosoma luminesces only when excited, and effective stimuli are mechanical, electrical, photic and chemical. The light appears in a punctate pattern over the whole surface; at each locus two closely spaced points of light can be resolved, which correspond to the pair of light organs at the entrance to the branchial sac of each zooid ( $P$. atlanticum, cf. Panceri, I873). In addition, there is a diffuse glow, the result of scattering and internal reflexion within the colony.

Light tactile stimulation of a fresh specimen produces a luminous wave, which spreads outwards from the stimulated region to the limits of the cylinder. A strong mechanical stimulus, such as squeezing the animal, causes the whole surface to lighten. Some recordings of the light emitted under mechanical stimulation are shown in Text-fig. $3\left(\mathrm{U}_{1}, \mathrm{U}_{2}, \mathrm{v}\right)($ p. 7I2) and Text-fig. 7 D. 
With repeated tactile stimulation, the luminescent response becomes progressively weaker, transmission finally ceases, and the light is confined to the region of stimulation (Text-fig. $7 \mathrm{E}$ ).

It has long been known that luminescence in Pyrosoma can be induced by illumination and a Pyrosoma in the dark will respond to the flash of another Pyrosoma by luminescing in turn. When a weak light from a torch is shone upon a colony, it responds by flashing (Nicol, I955a, p. 312, fig. 9). The response to weak illumination appears to be of the same character as that induced by tactile stimulation; it begins with a local glow which spreads as a wave over the colony. An instance was observed in which the light, after proceeding from one end of the colony to the other, gradually retreated to the end first illuminated, where the light outlasted the response elsewhere.

The luminescent flashes of Pyrosoma are rather slow and prolonged compared with those of many other luminescent animals. The following measurements for P. atlanticum are given as examples.

Specimen I cm long. Tactile stimulation evoked transmitted luminous waves. Duration of response $13.8 \mathrm{sec}$. Time to maximum $\mathrm{I} \cdot 06 \mathrm{sec}$; time to $\frac{1}{2}$ maximum $0.4 \mathrm{I} \mathrm{sec}$; decay time $\mathrm{I} 2.8 \mathrm{sec} ; \frac{1}{2}$ decay time $\mathrm{I} \cdot 39 \mathrm{sec}$. Most of the response was finished $\left(\frac{1}{2}\right.$ decay) by $2.5 \mathrm{sec}$ (temp. $25.5^{\circ} \mathrm{C}$ ).

Specimen $10 \mathrm{~cm}$ long. Tactile stimulation produced transmitted luminous waves. Time to maximum from first deflexion, $0 \cdot 4-\mathrm{r} \cdot 6 \mathrm{sec}$. For a response lasting $8 \frac{1}{2} \mathrm{sec}$, time to maximum lasted $\mathrm{I} \cdot 6 \mathrm{sec} ; \frac{1}{2}$ maximum was reached in I sec; time for $\frac{1}{2}$ decay was $2.9 \mathrm{sec}$ (temp. $25.5^{\circ} \mathrm{C}$ ).

Specimen $3 \mathrm{~cm}$ long. Local responses to electrical stimulation. Latency varied from 0.1 to $0.4 \mathrm{sec}$. In a response lasting $7.2 \mathrm{sec}$, maximum intensity was reached in $0.3 \mathrm{sec} ; \frac{1}{2}$ maximum in $0.15 \mathrm{sec} ; \frac{1}{2}$ decay from maximal deflexion occupied $3.3 \mathrm{sec}$ (temp. $25 \cdot 5^{\circ} \mathrm{C}$ ).

For $P$. elegans ( $P$. atlanticum), Polimanti (I9II) found that the response varied from 5 to $30 \mathrm{sec}$ (average ro $\mathrm{sec}$ ). Latencies varied from I to $5 \mathrm{sec}$; the average for photic stimuli was $5 \mathrm{sec}$. With very weak photic stimuli, the latency was prolonged; in general, the latency was shorter with stronger stimuli.

Nerves to the photogenic organs have not been detected, and it has been claimed that they are not innervated (Julin, I912; Neumann, I934). It is possible, of course, that the nerve fibres may be very fine, and may have been overlooked with the methods employed. The colonies are very sensitive to mechanical stimulation and, in the absence of innervation, would be acting as independent effectors. Following brief photic stimulation, transmission of luminescence across a colony can take place as a chain reaction, the light from one zooid stimulating its neighbours, and so on until the light wave has crossed the colony. As Burghause (I9I4) has shown, such transmission can occur even in the absence of nervous connexions. Pyrosomas often occur at the surface in shoals, and it seems likely that when one animal is excited, its light may cause other colonies nearby to luminesce. 
For histological examination specimens of $P$. atlanticum and $P$. spinosum were fixed in various solutions, including formalin, Bouin's, Helly's, Heidenhain-Susa, $80 \%$ ethanol, and osmic acid. Sections cut in paraffin wax and celloidin were stained with Ehrlich's haematoxylin and eosin, Biebrich scarlet and erythrosin, Heidenhain's haematoxylin and van Gieson, Masson's trichrome, Heidenhain-azan, Giemsa and Bodian's activated protargol.

In $P$. atlanticum the photogenic organs lie on each side of the pharynx above the peripharyngeal bands. They consist of a mass of photogenic cells, one or several tiers in thickness, lying in the peripharyngeal blood sinus. The cells are closely spaced, cell boundaries are sometimes distinguishable, but in many places the limits of separate cells cannot be resolved (Pl. I). In shape they tend to be spherical, about $9-15 \mu$ in diameter. In $P$. atlanticum, subsp. giganteum, cell size is given as $25-30 \mu$ (Julin, I9I2). The nucleus is peripheral, containing closely packed granular material; the cytoplasm is densely packed with inclusions, the presence of which is correlated with light production, and which constitute the photogenic paraplasm.

The paraplasmic inclusions are tubular structures, some $2 \mu$ in thickness, containing fine particles or granules. The tubules appear curved, like halfrings, but they may actually, as Julin (1912, I9I3) states, form a convoluted thread, only segments of which appear in focus at one time. This point is rather difficult to resolve. They stain with acid stains, eosin, erythrosin, Biebrich scarlet, orange G; diffusely and irregularly with haematoxylin; and with both xylidine ponceau and light green of Masson's trichrome stain in a spotty manner. In sections treated with Giemsa the inclusions are stained by the methylene blue. Their affinity for dyes is rather poor and they need to be overstained to confer much colour on them. Their structure is probably revealed as well, or better, by Bodian's silver proteinate, than by any of the more orthodox acidic dyes of the azo and xanthene groups. They are not dissimilar to the illustrations of Julin (I9I2), although much more densely packed than shown by him.

The photocytes of $P$. spinosum resemble those of $P$. atlanticum.

Pierantoni (I92I) claimed that the inclusions were symbiotic bacteria, and he described and illustrated dividing bodies and spores inside the photocytes. I have not seen such reproductive bodies and spores in the photogenic cells of my material. It seems to me that dense areas and apparent nodes in the cytoplasmic inclusions can be ascribed to overlapping of inclusions, or endviews of the inclusions which are seen vertically rather than in profile. Julin (I9I2) suggested that the inclusions contained nuclein (i.e. nucleoprotein), since internal granulations stained with haematoxylin. To test this possibility, sections were treated with Feulgen's reagent for deoxyribose nucleic acid. The test was negative: the photogenic inclusions were not coloured. Therefore, I can offer no additional evidence for the existence of symbiotic light bacteria. 
According to Julin (1912), ontogenetically the photogenic organs are formed from test cells, which are transmitted from one generation to the next. These test cells accompany the egg, and pass from cyathozooid to primary ascidiozooids. The test cells or follicular cells of the eggs of Pyrosoma are also luminous (Julin, 1913). In this developmental process, the photogenic inclusions (symbiotic bodies of Pierantoni) are supposed to be transmitted from the parent ascidiozooids to the luminous organs which develop in the ascidiozooids of the larval colonies (Buchner, 1914, I953; Pierantoni, 1914). Development and budding are described by Berrill (I950 $b$ ).

Measurements of light intensity were made from several specimens of P. atlanticum, and the results are presented in Tables 2 and 3 (pp. $7 \mathrm{II}$ and $7 \mathrm{I} 3$ ). For relative spectral composition I have used the spectral emission curve given by Kampa and Boden (1957, p. 88, fig. 8). According to these authors, the emission spectrum of $P$. atlanticum is bimodal, with a primary peak at about $480 \mathrm{~m} \mu$, and a smaller secondary peak near $525 \mathrm{~m} \mu$. The limits of this curve are far above the base-line, and it has been arbitrarily assumed that light emission extends from 420 to $600 \mathrm{~m} \mu$. In this respect it would resemble the blue light of other pelagic animals. Under mechanical stimulation, luminescence lasts up to $\mathrm{I} 7 \mathrm{sec}$. At a distance of $\mathrm{I} \mathrm{m}$ (in air), estimated radiant flux ranges from $\mathrm{I}^{\cdot} \cdot 4 \times \mathrm{IO}^{-8}$ to $\mathrm{I} \cdot 4 \times \mathrm{IO}^{-6} \mu \mathrm{W} / \mathrm{cm}^{2}$ receptor surface. Kampa \& Boden (1957) report light intensities of $0.8 \times 1 \mathrm{IO}^{-2}$ to $4 \times 1 \mathrm{IO}^{-2} \mu \mathrm{W} / \mathrm{cm}^{2}$ at a distance of $\mathrm{I} \mathrm{cm}$ (recalculated, according to the inverse square law, as $0.8 \times \mathrm{IO}^{-6}$ to $4 \times \mathrm{IO}^{-6} \mu \mathrm{W} / \mathrm{cm}^{2}$ receptor surface at $\mathrm{I} \mathrm{m}$ in air).

Pyrosomids are warm-water planktonic organisms, usually found at depths of less than $500 \mathrm{~m}$, but which have been taken as deep as $2850 \mathrm{~m}$. P. atlanticum, in its various subspecies, is cosmopolitan in distribution. P. spinosum is found in the Atlantic, Indian and Pacific Oceans (Ihle, I9I0; Metcalf \& Hopkins, 1919; Thompson, 1948; Berrill, I950 a).

\section{Searsia koefoedi Parr}

TELEOSTEI

One living specimen was captured ('Sarsia' Sta. no. 23, cruise 3/57). This is a black, bathypelagic species, previously recorded from the North and South Atlantic, the Mediterranean and the Indian Ocean (Brauer, I906; Norman, 1930; Beebe, 1933; Parr, 1937, 1951; Maul, 1948).

\section{EXPLANATION OF PLATE I}

Photomicrographs. A. Light organ of Pyrosoma atlanticum, showing photocytes. $\times$ I650. B. Light gland (postclavicular organ) of Searsia schnakenbecki. $\times 25$. C. Cellular contents of light gland of S. schnakenbecki. 'Red cells', light; 'blue cells', dark. × I 1oo. D. Photophore (anal organ, series $A O$ ) of Myctophum punctatum. $\times 265$. c.t., connective tissue; l., light gland; l.s., lenticular enlargement of scale; $p$, photocytes; ph.t., photogenic tissue; sc., scale; $s l$., striated layer. 

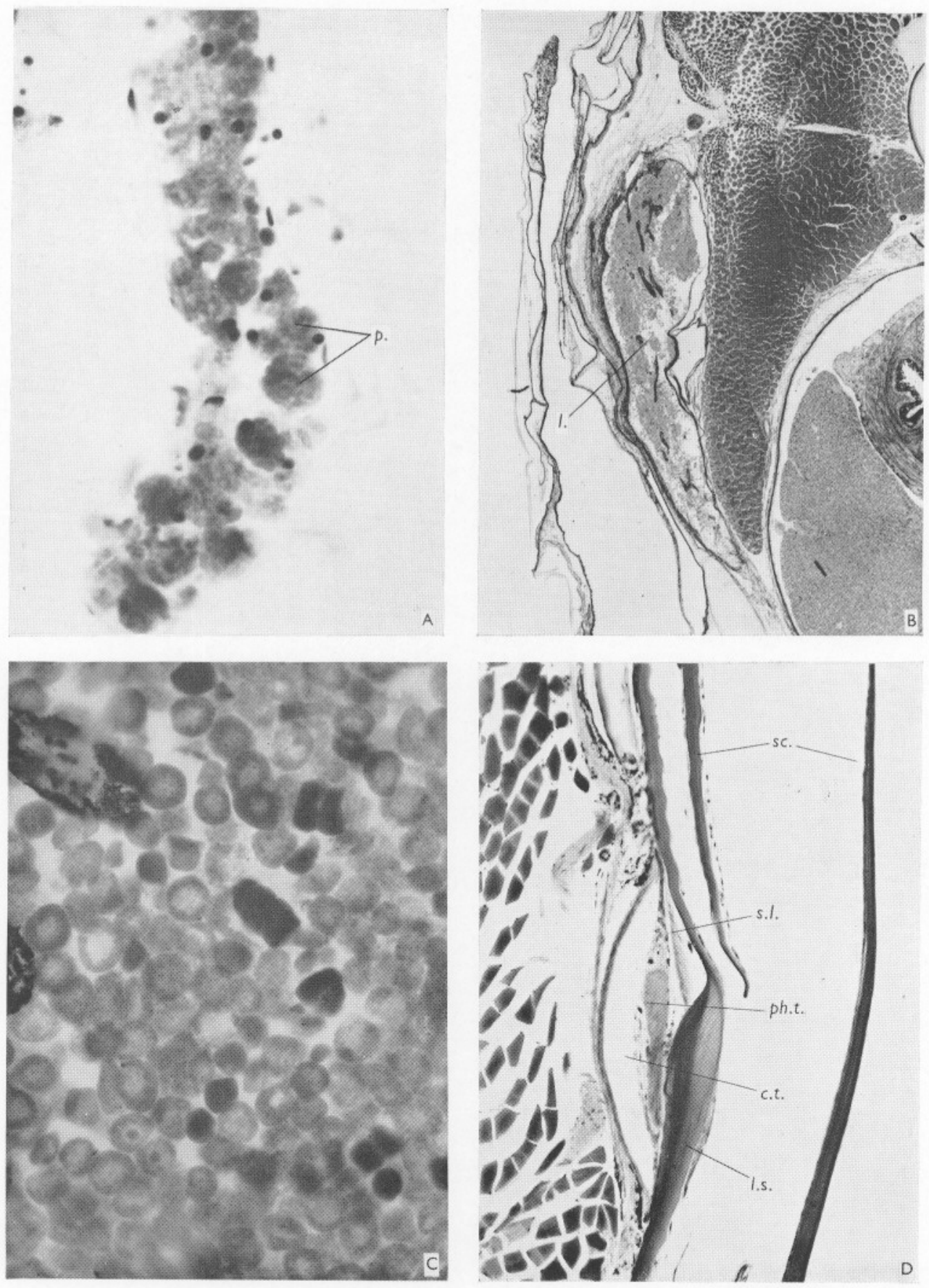

(Facing p. 726) 
Light organs appear as follows (Text-fig. Io): a transverse linear thoracic organ $(T h O)$, appearing as a depression with a white fleck at one end; a subventral V-shaped organ, black in hue $(S V O)$; a pair of white supraventrals $(S p V O)$; a pair of supra-anal organs $(S A O)$; a pair of white postanals $(P A O)$; and a pair of white subcaudal organs (SCO). The postclavicular organ (PCO) is obvious. Other reputed light organs, not clearly discernible in my specimen, are the submental and posterioventrals. Opercular and branchiostegal organs are faint. On the other hand, there appears to be a trace of a light organ on the basal portion of the posterior ray of the pectoral fin. Gunther (in Norman, I930) observed that the light organs were red in life (see also Beebe, I93I; Parr, 1937). The shape of the supraclavicular process (=postcleithral or postclavicular organ) is illustrated by Beebe (1933) and shown in Text-fig. 9.

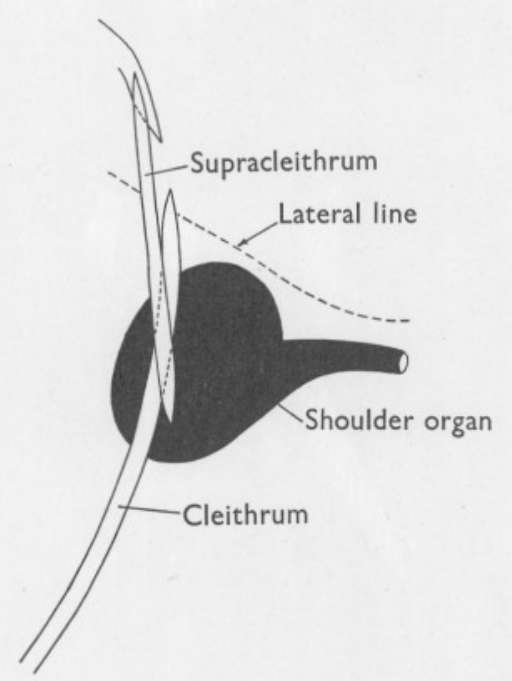

Text-fig. 9. Diagram of the postclavicular or shoulder luminescent organ of Searsia (=Bathytroctes) rostratus, copied from Beebe, 1933. The original drawing was made from a cleared specimen $32 \mathrm{~mm}$ long.

The animal was alive when brought to the surface, and it was seen to discharge a bright luminous cloud into the water when handled. The light appeared as multitudinous bright points, blue-green in colour. On repeated stimulation the light became weaker and ceased, and the fish died. Computation of radiant flux was carried out as described for $S$. schnakenbecki on p. 792). The luminous glow lasted about $4 \mathrm{sec}$. At a distance of $\mathrm{I} \mathrm{m}$ (in air), light intensity was about $2 \times 10^{-6} \mu \mathrm{W} / \mathrm{cm}^{2}$ receptor surface (Tables 2 and 3 ). The light of this specimen of $S$. koefoedi was about 5 times brighter than that of $S$. schnakenbecki, as measured in these few instances. 


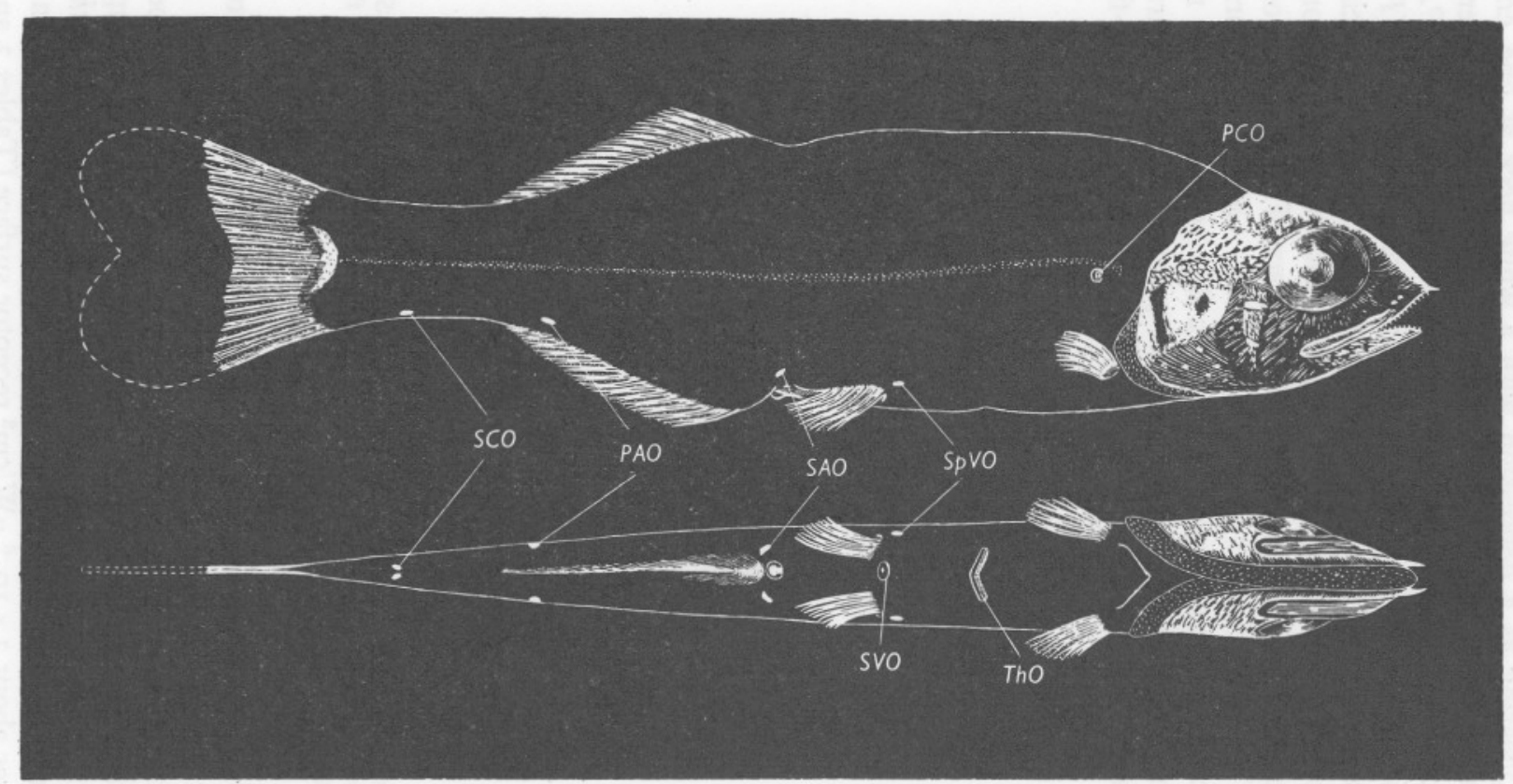

Text-fig. Io. Lateral and ventral view of Searsia koefoedi. Legend for light organs: $P C O$, postclavicular (shoulder) organ; $T h O$, transverse thoracic organ; $S V O$, subventral organ; $S p V O$, supraventrals; $S A O$, supra-anal organs; $P A O$, post-anal organs; $S C O$, subcaudal organ. $\frac{1}{2}$ natural size. 


\section{Searsia schnakenbecki Krefft}

One living and several dead specimens were captured ('Sarsia' Sta. no. 5, cruise 3/57). This fish provided a spectacular luminescent display. When gently stimulated by being lightly pressed with the fingers, it suddenly shot forth myriads of blue-green sparkș into the water. These brightly illuminated the whole dish with a glow lasting about 2 sec. The intensity of light was much greater than that usually recorded, and it was necessary to employ a piece of Chance neutral glass as a reducing filter when recording the responses. With repeated stimulation, the light gradually became weaker, and ceased after about six discharges. Since the fish lived only a short time, it was not possible to determine the spectral composition. In calculating light intensities, I made use of a spectral curve resembling that for Beroe light, but with the maximum displaced to $500 \mathrm{~m} \mu$. At a distance of $\mathrm{I} \mathrm{m}$ (in air), estimated values for radiant flux are $150 \times 10^{-9}$ and $430 \times 10^{-9} \mu \mathrm{W} / \mathrm{cm}^{2}$ (Tables 2 and $3, \mathrm{pp}$. 7II and 713 . For light with maximal emission at $480 \mathrm{~m} \mu$, estimated radiant flux would range from $130 \times 10^{-9}$ to $365 \times 10^{-9} \mu \mathrm{W} / \mathrm{cm}^{2}$.

Searsia schnakenbecki was described by Krefft (1953) from specimens captured in the region $63^{\circ} 20^{\prime}-40^{\prime} \mathrm{N}$., II-I2 $2^{\circ} \mathrm{W}$., depth of water $450-500 \mathrm{~m}$. It is probably bathypelagic in habits. My specimen has the following suppositional light organs, which largely agree with comparable organs described in the type specimen (Krefft, I953): submental ( $\mathrm{SmO})$; seven branchiostegal organs $(\mathrm{BrO})$; eye organ $(\mathrm{OO})$; opercular organ $(\mathrm{OpO})$; pair of pectoral organs $(\mathrm{PO})$; transverse thoracic organ $\mathrm{I}\left(\mathrm{ThO}_{1}\right)$; transverse thoracic organ 2 $\left(\mathrm{ThO}_{2}\right)$; pair of supraventrals $(\mathrm{SpVO})$; transverse subventral $(\mathrm{SVO})$; a posterioventral $(P V O)$; a pair of inferior ventral organs $(I V O)$; a pair of supraanal organs $(S A O)$; a pair of postanals $(P A O)$; and a subcaudal organ $(S C O)$. In addition, there is a black shoulder organ (postclavicular organ). The position of these various organs is shown in Text-fig. II.

Most of the surface of the fish is black, except for clear cheeks and cranial roof. The light organs $\mathrm{SmO}, \mathrm{BrO}, \mathrm{OO}, \mathrm{OpO}, \mathrm{PO}, \mathrm{SpVO}, \mathrm{IVO}, \mathrm{PVO}$ and $S C O$ appear as white spots or flecks on a black ground. Transverse thoracic organ I $\left(T h O_{1}\right)$ is grey in colour, $\mathrm{V}$-shaped, with the apex of the $\mathrm{V}$ pointing anteriorly. Transverse thoracic organ 2 is a grey transverse stripe with a white fleck at either end. The transverse subventral organ (SVO) is a broad grey transverse stripe. The posterioventral organ is a raised wedge-shaped mound, black in colour. The postcleithral organ $P c O$ ) is a raised papilla lying on the lateral body wall above the pectoral fin.

All these organs have been called light organs, although they have not been seen luminescing in the living fish. Parr (I95I) described the shoulder or postcleithral organ of the Searsidae as a large sac lying underneath the skin, often extending forward partly underneath the upper posterior portion of the cleithrum, and opening to the exterior by a tube. The sac has a black lining, 


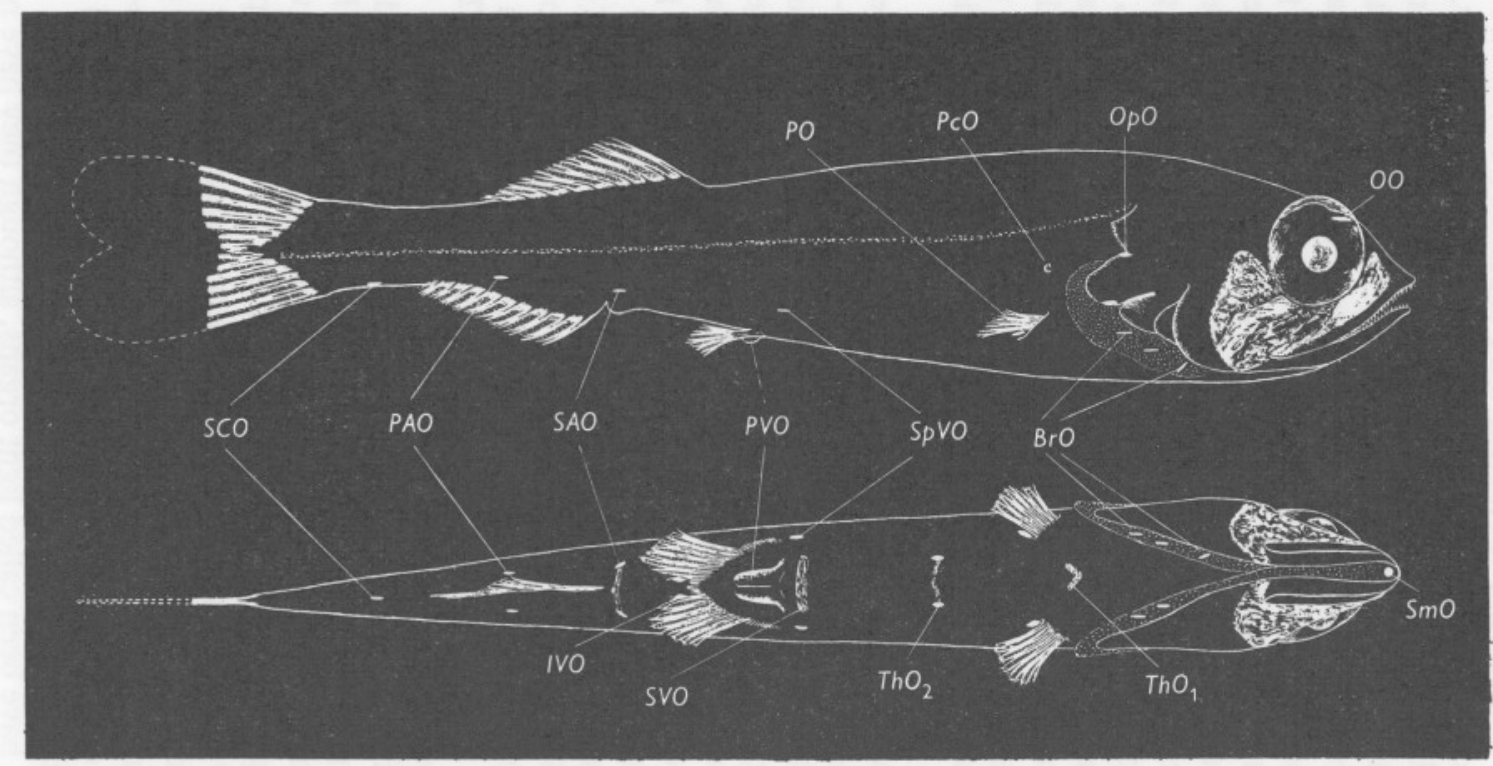

Text-fig. II. Lateral and ventral view of Searsia schnakenbecki. Legend for light organs: $\mathrm{SmO}$, submental; $\mathrm{BrO}$, branchiostegal; $O O$, eye organ; $O p O$, opercular organ; $P O$, pectoral organ. $T h O_{1}$, transverse thoracic organ $\mathrm{I}$. $\mathrm{ThO}_{2}$, transverse thoracic organ $2 ; S p V O$, supraventrals; $S V O$, transverse subventral; $P V O$, posterioventral; $I V O$, inferior ventral; $S A O$, supra-anal organ; $P A O$, postanal organs; $S C O$, subcaudal organ; $P c O$, postclavicular (shoulder) organ. $\frac{1}{2}$ natural size. 
and is traversed from outer to inner wall by irregular strands or columns of soft tissue; it discharges through a tube, which also has a black lining. Parr (I95I) and Tucker (I954) suggest that the function of this organ lies in the discharge of a luminous secretion, which I have observed.

Histological observations were made on the luminescent gland of S. schnakenbecki. The specimen of S. schnakenbecki was fixed in formalin initially, and some time later was post-fixed in Wittmaack's fluid. Sections were cut in celloidin at $15 \mu$, and treated with a trichrome stain (iron haematoxylin, Bordeaux red, and aniline blue).

The luminescent gland lies deep in the dermis, immediately outside the skeletal musculature (P1. IB). It is elongated dorsoventrally, and is about one-fifth the height of the fish (about $2.3 \mathrm{~mm}$ high and $0.5 \mathrm{~mm}$ wide). The walls and internal trabeculae consist of a thick layer of dense connective tissue, staining with aniline blue. This tissue contains a dense population of yellowish black (by transmitted light) melanophores, some of which extend, as flattened cells, over the internal surface of the gland. There is no recognizable continuous epithelial lining.

In the connective tissue walls of the gland and in the trabeculae there are small 'violet cells' (P1. I c). These are scattered individually, or grouped in clumps which give the impression of originating by division. Many of these cells also occur on the internal surface of the gland, and a few in the internal lumen; some of the cells seem to be in the process of migrating through the connective tissue into the lumen of the gland. The cells are coloured deep violet by the stain; the nucleus is very dense and dark, and the basophilic cytoplasm contains purple granules. These violet cells are only about $5 \mu$ in diameter, and the cytoplasm is rather sparse.

Lying in the lumen of the gland are many spherical 'red cells'. These are large, ranging from 8 to $40 \mu$ in diameter. The body of the cell or spherule (the 'cytoplasm') is packed with acidophilic granules, coloured pink by the dye; staining affinity is rather weak. In the centre of the spherule is a clear area, representing the nucleus, and containing a few fine chromatic threads.

A third cell type is found in the gland lumen, the 'blue cells'. These are smaller in size, around $6-8 \mu$, the nucleus is more prominent and deeply staining, and the basophilic cytoplasm contains blue granules. All kinds of transitional stages appear to exist between the 'blue' and 'red' cells, the nucleus in such intermediates becoming fainter, the cell volume increasing, and the cytoplasm shifting from basi- to acidophilic.

The picture that emerges is the following. The large acidophilic spherules appear to be the photogenic bodies. Presumably, when expelled, they become disrupted and activated and they then emit light. There is a reasonable degree of transition between the small 'violet' cells in the gland wall and the large 'red' cells in the gland lumen, and it is not improbable that the violet basophils represent the generative tissue. The latter cells, passing into the gland 
lumen, gradually become transformed into the acidophilic spherules. This picture is rather an extraordinary one, and is offered with some hesitation, since a closely comparable situation has not been described in other luminescent animals producing a luminous secretion. Perhaps a distant analogy can be drawn with the proliferating epithelial tissue within the testis, or the sebaceous glands of mammalian skin. There is no continuous epithelial lining in the light gland of this specimen, however. Although this appearance may be an artifact, due to glandular discharge, fixation, etc., this is rather unlikely. Rather the generative cells appear to originate in the connective tissue itself, and subsequently pass into the gland lumen. In two other luminous teleosts (Malacocephalus and Monocentris), luminous secretion is produced by break down (cytolysis) of epithelial cells lining the light organs (Hickling, 1926; Okada, 1926); Harvey (1952) implicates bacteria in the luminescence of these two fish.

\section{Myctophum punctatum Rafinesque}

Lantern fish were attracted to the side of the boat by hanging a lamp over the side after dark. Fish which came to the surface were captured in a hand net. All specimens were $M$. punctatum. Position $47^{\circ} 00^{\prime} \mathrm{N} ., 6^{\circ} 05^{\prime} \mathrm{W}$. ('Sarsia' Sta. no. 8, cruise 3/57).

The myctophids examined were $8-9 \mathrm{~cm}$ in length (snout to tip of tail). This species possesses many large photophores on head and trunk, and the photophores have been labelled and numbered for systematic purposes (see Fraser-Brunner, 1949, fig. 2). Myctophids flash periodically when kept in aquaria. The light appears blue to the eye. To record luminescence, a fish was placed in a small dish beneath the photomultiplier, and was stimulated mechanically by handling it. With this treatment, the fish responds by lighting up all its photophores.

The spectral composition of myctophid light is not known, and I used the spectral curve of Chaetopterus light (Text-fig. 4, p. 714) for purposes of calculation. Since the light of both animals is blue, and since the photomultiplier has a fairly flat response below $500 \mathrm{~m} \mu$, any error occasioned by this procedure will be small.

Values for calculated radiant flux are given in Tables 2 and 3 (pp. $7 \mathrm{II}$ and $7 \mathrm{I} 3$ ). The light was measured at a distance of about $95 \mathrm{~mm}$, and the recordings are of the light emitted by about half the photophores borne by the fish. The light is emitted in periodic flashes, sometimes grouped into rhythmic bursts. Each flash lasts about $0.5 \mathrm{sec}$ and bursts of flashes last up to $3-4 \sec$ (Text-fig. $3, \mathrm{w}_{1}, \mathrm{w}_{2}$ ). At a distance of $\mathrm{I} \mathrm{m}$ in air, minimal estimates of radiant flux are $\mathrm{I} \times \mathrm{IO}^{-9} \mu \mathrm{J}$ to $50 \times 10^{-9} \mu \mathrm{W} / \mathrm{cm}^{2}$ receptor surface. Owing to the large size of the source, viz. a lantern fish with all its photophores glowing, decrease of intensity with distance is less than that predicted by the inverse square law; consequently, these values for radiant flux may be slightly low. There is a further difficulty 
owing to the circumstance that the photophores of lantern fish possess lenses or focusing devices, the optical characteristics of which are unknown; it is highly unlikely that all the photophores bring their light into focus in the same plane. For these various reasons, recalculated estimates of radiant flux at distances other than those actually measured can be regarded only as a rough estimate.

With regard to their histology, the photophores of Myctophum and Scopelus have been examined microscopically by earlier workers (Emery, 1884; Brauer, 1908; Ohshima, I9I I). My own observations were made on the anal organs (series $A O$ ) of Myctophum punctatum. These were fixed in Bouin's, cut in celloidin, and stained with Ehrlich's haematoxylin and eosin, or with a trichrome stain containing iron haematoxylin, Bordeaux red, and aniline blue.

A photophore is overlapped externally by I or 2 scales, and the scale immediately overlying the organ is intimately associated with its structure (P1. ID). At the surface of the light organ the scale is thickened into a lenticular swelling; there is the usual epidermal covering. Beneath the scale lies a striated layer (the 'schüllelformige Organe' of Brauer and the 'peculiar membrane' of Ohshima). In section this shows transversely arranged striae or fibrils, which stain blue with haematoxylin. Underneath the striated layer is a patch of photogenic tissue, consisting of narrow elongated cells, with long axes directed dorsoventrally. These have narrow elongated nuclei, the cytoplasm has a somewhat indistinct fine granular appearance and stains blue with haematoxylin. The photogenic cells are in the neighbourhood of $40-50 \mu$ long; although cell boundaries are difficult to distinguish, the cells seem to be about $5 \mu$ broad.

The photogenic mass is invested with a thin limiting membrane of flattened cells, possibly a connective tissue sheath (P1. ID). Filling the intervening space, between the photogenic mass and the external sheath, is a loose connective tissue (mucous connective tissue of Emery, gelatinous layer of Brauer and Ohshima). This has a faintly eosinophilic ground substance, containing flattened nuclei. Investing the organ externally is a dense connective tissue sheath, consisting of an internal homogeneous eosinophilic layer, and an external dense basophilic layer. Occasional pigment cells, or extensive streaks of black pigment, are found behind the connective tissue sheath. The organ is ringed with pigment cells, which extend a short distance down over the dorsal face of the organ. The arrangement of the pigment and the asymmetrical arrangement of the lens and photogenic tissue all indicate that the light from these organs is directed downwards.

Since the lens system and aperture are wider than the actual photogenic tissue, they will have the action of enlarging the apparent source. In addition, the lens may have a collimating effect. 


\section{Leptostomias sp.}

A Leptostomias, close to L. macropogon Norman, was captured alive, at 'Discovery' Sta. no 3344, on 18 October 1955. It was observed in the dark room. Notes made at the time read: 'The long chin barbel had an enlarged cream coloured tip. When the fish was sharply displaced, or the tentacle tip was gently stroked with a camel-hair brush, the tentacle tip gave off a faint bluish luminescence. Faint glow, lasting about a second.'

L. macropogon has been captured previously in the South Atlantic (Norman, 1930).

The barbel bulb is also yellow in fresh specimens of $L$. gladiator and $L$. bermudensis; the luminescence, apparently, has not been seen. The barbel of a living Chirostomias pliopterus gave off a steady pink glow anteriorly, and a white glow posteriorly. The bulb of a living male Eustomias bibulosus gave off a distinctly green light in three brilliant flashes (Beebe \& Crane, 1939). Beebe (1935) observed red and blue lights in the barbels of deep-sea melanostomiatids during dives in his 'bathysphere'.

\section{LUMINESCENCE AND REFLEXION OF LIGHT FROM ANIMAL SURFACES}

It is well known that many animals from bathypelagic waters, below the level of light penetration, are black or red in colour, e.g., Scyphomedusae, nemertines, Crustacea, and teleosts. In upper, dimly lit waters, some animals are translucent, motley coloured, or have a silvery sheen. Thus silvery and palecoloured fishes are mostly found in the upper $500 \mathrm{~m}$, black and brown species at greater depths. This correlation of colour with depth is not absolute, but is striking enough when examining net hauls from various depths, and there has been much speculation concerning its significance (Murray \& Hjort, I912; Marshall, 1954). The commonest suggestion is that dark colours (red, black and brown) serve to reduce reflexion to a minimum in deep water, and thus decrease the animal's chances of being seen. With these ideas in mind it seemed worth while to make some actual measurements of reflexion from bathypelagic species.

Few attempts have been made to measure reflexion from animals, although many curves are available for reflexion characteristics of plants (leaves, flowers, etc.). Using a Hardy photoelectric recording spectrophotometer, Edwards \& Duntley (1939) made a detailed study of pigments and colours of human skin. They measured reflexion from the skin surface, transmission through the skin and absorption by the skin and its contained pigments. Deanin \& Steggerda (1948) have used the same instrument for measuring melanin dispersion in the frog.

Measurements of reflexion were made with a Unicam instrument, namely 
the 'diffuse reflectance attachment' (S.P. 540) coupled to a 'photoelectric quartz spectrophotometer' (S.P. 500). This instrument measures diffuse reflectance, using a block of magnesium carbonate as a reference standard. The reflexion coefficient of $\mathrm{MgCO}_{3}$ ranges from 0.967 at $450 \mathrm{~m} \mu$ to 0.989 at $650 \mathrm{~m} \mu$ (Handbook of Chemistry and Physics, 1949). The characteristics of the instrument were essayed by measuring reflectance from green leaves: two resultant curves for peony leaf (A) and Euonymus leaf (B) are shown in Textfig. I2. The reflectance characteristics of these leaves are determined in large part by the properties of their chlorophylls and carotenoids; reflectance is less in the more glossy leaf of Euonymus, as might be anticipated. The instrument measures very little direct reflexion. At $450 \mathrm{~m} \mu$, reflexion from a disc of polished silver was $6 \%$, compared with published values of 0.90 for reflexion factor (direct) (Walsh, I953).

\section{CRUSTACEA}

Measurements were made of reflexion from the integument of the deep-sea shrimp Acanthephyra multispina ('Sarsia' Sta. nos. 5 and Io, cruise 3/57). The data are plotted in Text-fig. I3 (curves D and E). Both $A$. purpurea and A. multispina are deep red in colour, owing to a heavy deposition of carotenoids in the body coverings. Frozen specimens of A. multispina were saved for pigment extraction and treated as follows. After thawing the animals the integument was stripped off and extracted with acetone. Water and ethanol were added, and the pigment was transferred to petroleum ether (b.p. 40$60^{\circ} \mathrm{C}$ ). Absorption was read in a spectrophotometer (Unicam S.P. 600). The solvent was evaporated in vacuo, and the pigment redissolved in $\mathrm{CS}_{2}$. Absorption was read in the spectrophotometer. Absorption curves in petroleum ether and $\mathrm{CS}_{2}$ are shown in Text-fig. I3 (A, B). These curves are identical with those for astaxanthin in the literature (Karrer \& Jucker, I948; Goodwin, 1952).

A piece of white filter-paper was soaked in the pigment solution and dried. Reflectance of the coloured paper was read in the spectrophotometer (Unicam S.P. $540+$ S.P. 500). A curve for diffuse reflectance (corrected for reflexion characteristics of the paper itself) is shown in Text-fig. I3 (c).

Carotenoids sometimes occur as carotiprotein complexes, for example crustacyanin, the blue carotenoid-protein of lobster shell. Wald, Nathanson, Jencks \& Tarr (1948) have succeeded in extracting the latter by employing dilute citric acid. I tried grinding up the integument of $A$. multispina, and extracting with $\mathrm{O} \cdot \mathrm{I} M$ citric acid. No pigment was removed by this process, indicating that the astaxanthin occurs in a free state.

$A$. purpurea and $A$. multispina are deep red in colour except for the black eyes. The entire surface of the body is covered with greatly expanded chromatophores having long filamentous processes. The cuticle itself is pigmented, appearing amber yellow between the chromatophores. In Systellaspis debilis, 


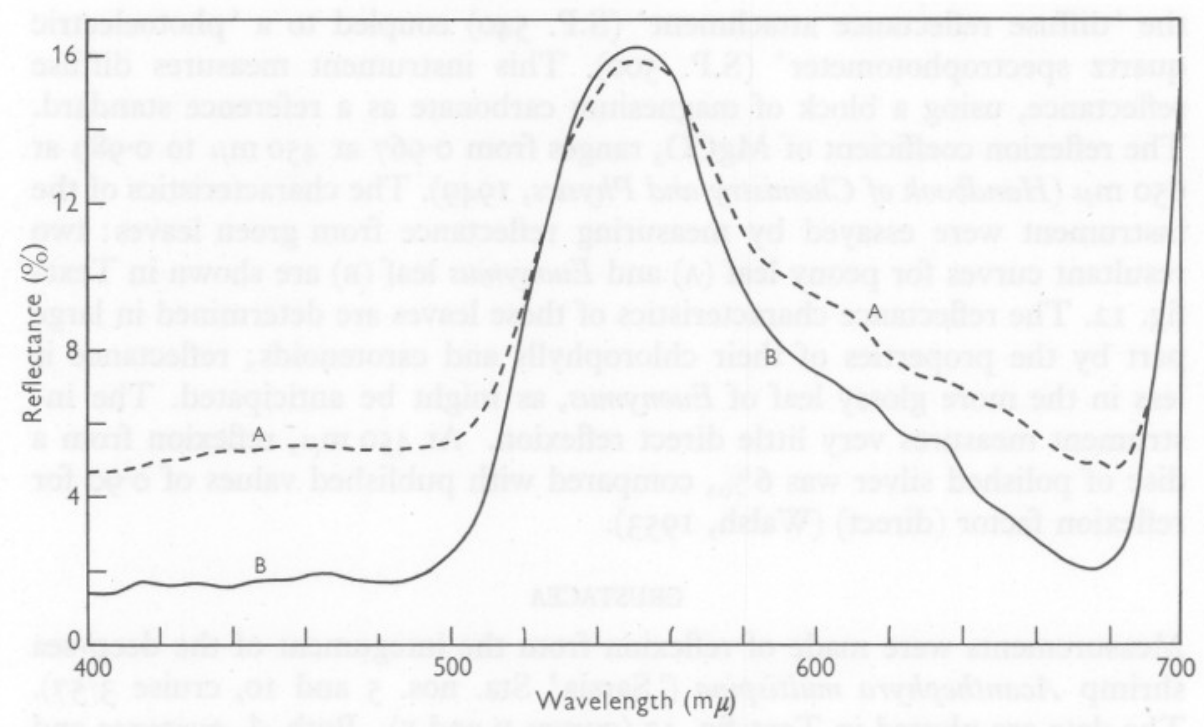

Text-fig. I2. Reflectance curves for green leaves of peony (A), and Japanese Euonymus (B), as determined with the Unicam reflectance attachment (S.P 540).

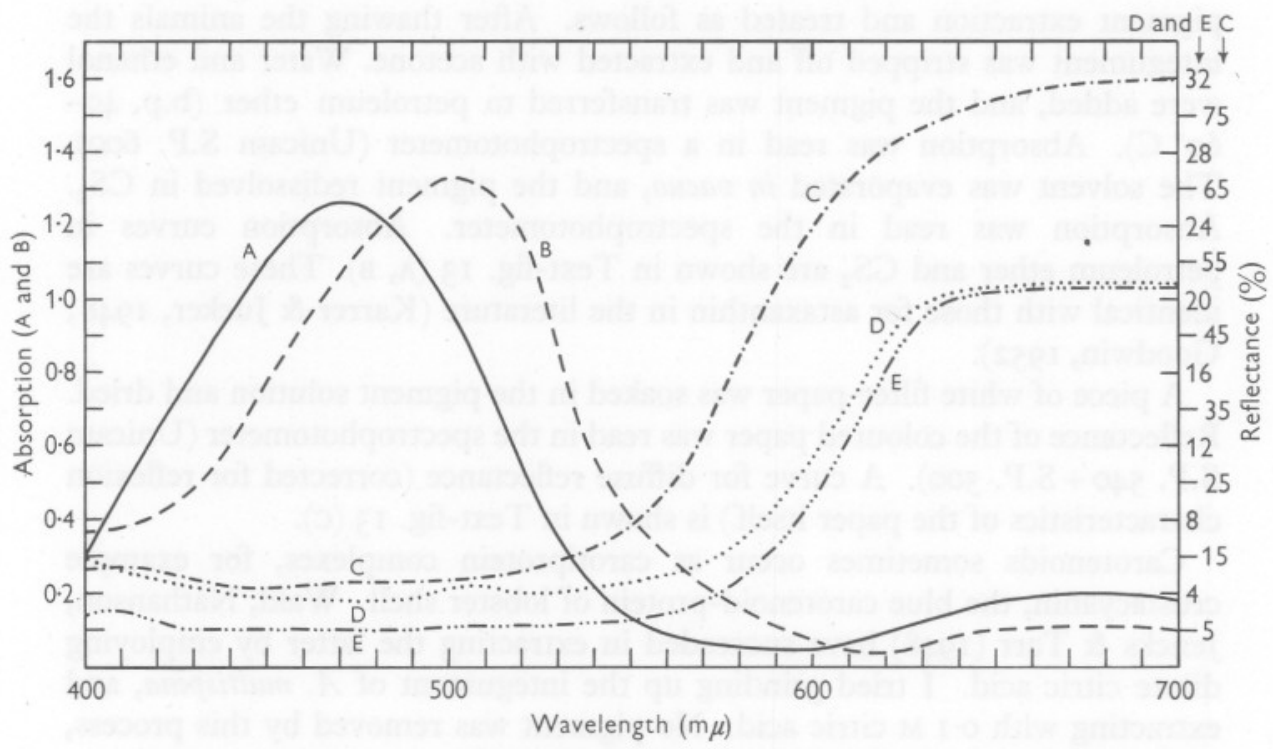

Text-fig. 13. Spectral curves relating to Acanthephyra multispina. A and B. Absorption curves for carotenoid pigment (astaxanthin) extracted from the integument: $\mathrm{A}$, in petroleum ether; B, in $\mathrm{CS}_{2}$. I cm cells. Figures at the left for curve A (readings in petroleum ether), $\times$ IO; for curve B (readings in $\mathrm{CS}_{2}$ ), $\times 5$. C. Reflectance of filter-paper impregnated with astaxanthin. D, E. Reflectance from surface of the animal. Scales for C, D and E shown at the right. 
Dennell (I955) found that the deep red pigment of the body was confined to the cuticle.

The characteristics of the reflectance curves (Text-fig. I3) show good agreement with the absorption properties of extracted pigment, which seems to be astaxanthin. The reddish coloration of Acanthephyra is thus produced largely by the red astaxanthin pigment, located in red chromatophores and occurring freely in the cuticle.

\section{TELEOSTS}

The reflectance of several species of deep-sea fish was measured, and the data are assembled in the curves of Text-fig. I4. Specimens were: Argyropelecus olfersi Cuv. ('Sarsia' Sta. no. 5, cruise 3/57); Cyclothone sp. ('Sarsia' Sta. no. 6, cruise 3/57); Xenodermichthys copei Gill ('Sarsia' Sta. no. Io, cruise 3/57); and Chauliodus sp. ('Sarsia' Sta. no. 5, cruise 3/57).

The Cyclothone was a black bathypelagic species. Two sets of measurements showed low reflectance, ranging from 3 to $4 \%$ in the visible range (400$700 \mathrm{~m} \mu$ ). Reflectance is maximal in the blue, falls off slightly at longer wavelengths in the green and yellow, and shows a slight rise again in the red (above $650 \mathrm{~m} \mu)$.
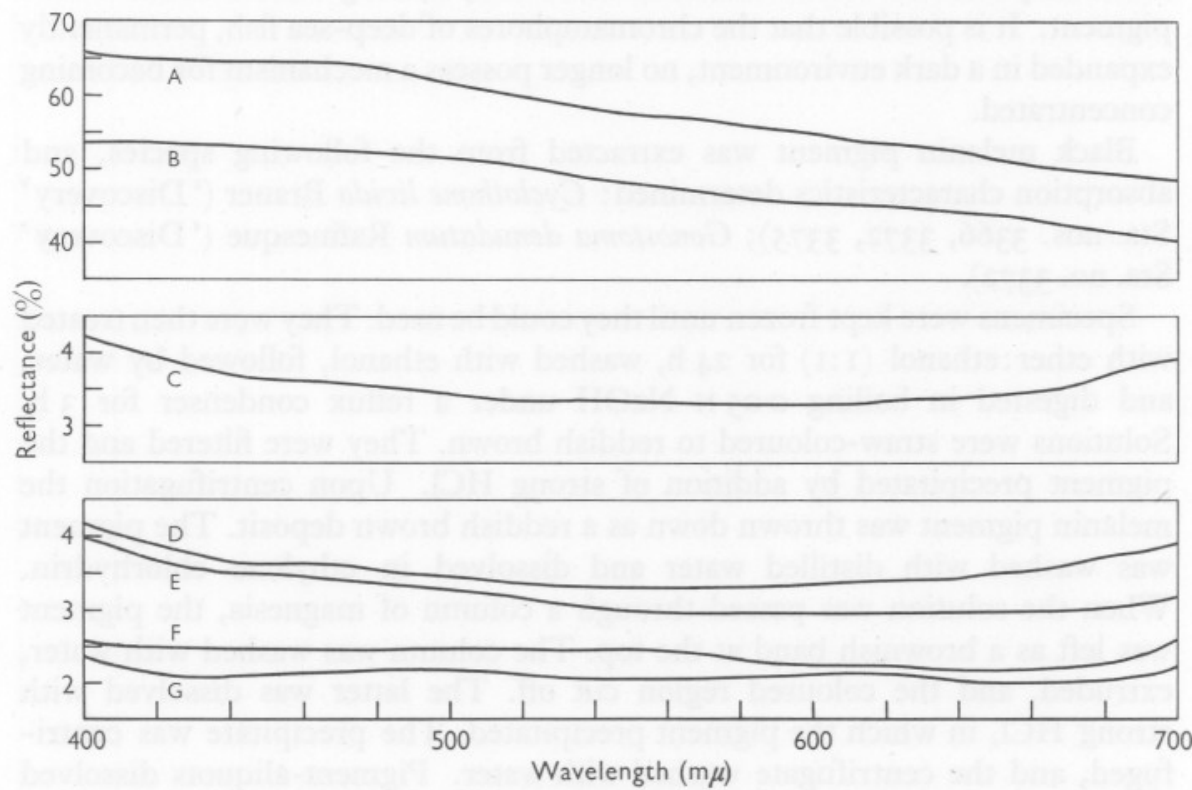

Text-fig. I4. Reflexion from the integument of some deep-sea fish. Measurements made with Unicam instrument (S.P. $540+$ S.P. 500). Ordinates, reflexion as percentage of $\mathrm{MgCO}_{3}$ standard (maximum = I00). Abscissae, wavelength. A, B. Argyropelecus olfersi Cuv, abdominal wall and trunk. C. Xenodermichthys copei Gill, lateral abdominal wall. D, E. Cyclothone sp., flank of two specimens. F, G. Chauliodus sp., lateral peduncle and ventral surface of trunk, respectively. Note changes of scale on ordinates. 
The black pigment in the skin of Cyclothone is contained in melanophores, which are densely distributed over the surface of the body. In freshly caught specimens these are all expanded, and their processes touch one another, thus forming a mosaic. Several shapes of melanophores can be recognized: cells with fine irregular, branching and radiating processes; cells with a dark pigmented centre from which radiate lobate processes; and more or less hexagonal-shaped pigmented cells, in which the processes are short or wanting. The melanophores lie in two layers, the more superficial cells having fine branching processes, while the deeper cells have coarser lobate processes, or are hexagonal in shape. The fin rays possess a layer of black pigmented cells on either side, and the ventral photophores lie in black pigmented capsules. There is no trace of other kinds of chromatophores, neither guanophores nor lipophores. Light shines through and between the processes of the cells, the latter being only partially absorbing. The muscles are translucent; the visceral region, owing to a black peritoneum, and much of the head, are opaque.

Pieces of fins of freshly caught (dead) specimens were placed in fish-Ringer, to which was added adrenaline to make $\mathrm{I} / \mathrm{I} 00,000$ and $\mathrm{I} / \mathrm{I} 0,000$. No contraction of the melanophores occurred in $\mathrm{I} h$. Adrenaline is a strong stimulant of chromatophores of coastal and freshwater fish, causing concentration of the pigment. It is possible that the chromatophores of deep-sea fish, permanently expanded in a dark environment, no longer possess a mechanism for becoming concentrated.

Black melanin pigment was extracted from the following species, and absorption characteristics determined: Cyclothone livida Brauer ('Discovery' Sta. nos. 3366, 3372, 3375); Gonostoma denudatum Rafinesque ('Discovery' Sta. no. 3372).

Specimens were kept frozen until they could be used. They were then treated with ether: ethanol (I:I) for $24 \mathrm{~h}$, washed with ethanol, followed by water, and digested in boiling $0.05 \mathrm{~N} \mathrm{NaOH}$ under a reflux condenser for $3 \mathrm{~h}$. Solutions were straw-coloured to reddish brown. They were filtered and the pigment precipitated by addition of strong $\mathrm{HCl}$. Upon centrifugation the melanin pigment was thrown down as a reddish brown deposit. The pigment was washed with distilled water and dissolved in ethylene chlorhydrin. When the solution was passed through a column of magnesia, the pigment was left as a brownish band at the top. The column was washed with water, extruded, and the coloured region cut off. The latter was dissolved with strong $\mathrm{HCl}$, in which the pigment precipitated. The precipitate was centrifuged, and the centrifugate washed with water. Pigment-aliquots dissolved in ethylene chlorhydrin and boric-borate buffer at $\mathrm{pH} 9$; these were examined in a spectrophotometer (Unicam S.P. 500). Specimens of Cyclothone, preserved in formalin for I month, were extracted in a like manner (Gortner, I9I I; Lea, 1945; Serra, 1946; Smyth, Porter \& Bohren, I95I).

Representative absorption curves for the pigments are shown in Text-fig. 15. 
They are typical of melanin curves: melanin is a reddish pigment showing high absorption in the blue, and minimal absorption at long wave-lengths. Visceral (peritoneal) and skin pigments are similar (Text-fig. I6); formol causes little or no change in the absorption characteristics of the melaninpigment (Text-fig. I6).

When Text-figs. I4 and 15 are compared, it will be apparent that the melanin of the skin contributes very little to the spectral composition of the reflected light; the slight rise in the reflectance curves, about $600 \mathrm{~m} \mu$, amounting to about $\mathrm{I} \%$, is caused by melanin in the skin. The surfaces of black bathypelagic species measured showed very low reflexion: Chauliodus, $2-2 \frac{1}{2} \%$; Cyclothone, $3-4 \%$; Xenodermichthys, 3-4\%. Much of this reflexion probably originates in surface tissue lying between the chromatophores. Indirect reflexion is much higher in Argyropelecus, which possesses a silvery surface, around 40-65\%.

\section{DISCUSSION}

Recent estimates of the intensity of light emitted by marine animals are collated in Table 3 (p. 713). For comparison, they are brought to a common basis of energy units $/ \mathrm{cm}^{2}$ receptor surface at a distance of $\mathrm{I} \mathrm{m}$. Although this procedure involves some unknown degree of error, owing to probable deviation from the inverse square law, it at least provides rough estimates of orders of magnitude.

The estimates in Table 3 are all derived from photoelectric measurements. There are, in the literature, some earlier estimates of the brightness of animal light, based on visual comparison.

Dennell (1955) cites a figure of 0.0I mlam for the luminance of bathypelagic decapod Crustacea, such as Systellaspis and Hoplophorus. On the assumption that the visible light-emitting surface is about Io $\mathrm{mm}^{2}$, this value for luminance is approximately equivalent to $3.18 \times 10^{-4} \mathrm{~m}$ lumen $\mathrm{cm}^{2}$ receptor surface and $2.3 \times \mathrm{IO}^{-3} \mu \mathrm{W} / \mathrm{cm}^{2}$ receptor surface at a distance of I cm (Dennell, I940). This intensity is about the same as that of Euphausia pacifica (see Kampa \& Boden, 1957) and seems to be of the right order of magnitude.

According to Nichols (1924), the light of the ctenophore Mnemiopsis leidyi has a brightness of $0.1 \mathrm{I}-0.30 \mathrm{mlam}$. For mature animals about $100 \mathrm{~mm}$ long, these values are roughly equivalent to radiant fluxes of 0.4 to $\mathrm{I} \mu \mathrm{W} / \mathrm{cm}^{2}$ at I cm (Mayer, 1912; Coonfield, 1936). They are of about the same order of magnitude as recorded by Clarke \& Backus (1956) (see Table 3).

The light organ of the coastal fish Photoblepharon palpebratus, according to Steche (1907), has a brightness equivalent to a surface illuminated with 0.0024 Meter-Kerze, or $0.0022 \mathrm{~lx}$. The light organ has a flattened oval shape, II $\times 5 \mathrm{~mm}$ in dimensions; the light is produced by symbiotic luminescent bacteria. The light is reported to be greenish blue in colour, and probably is not greatly different in relative spectral composition from the curve for the 


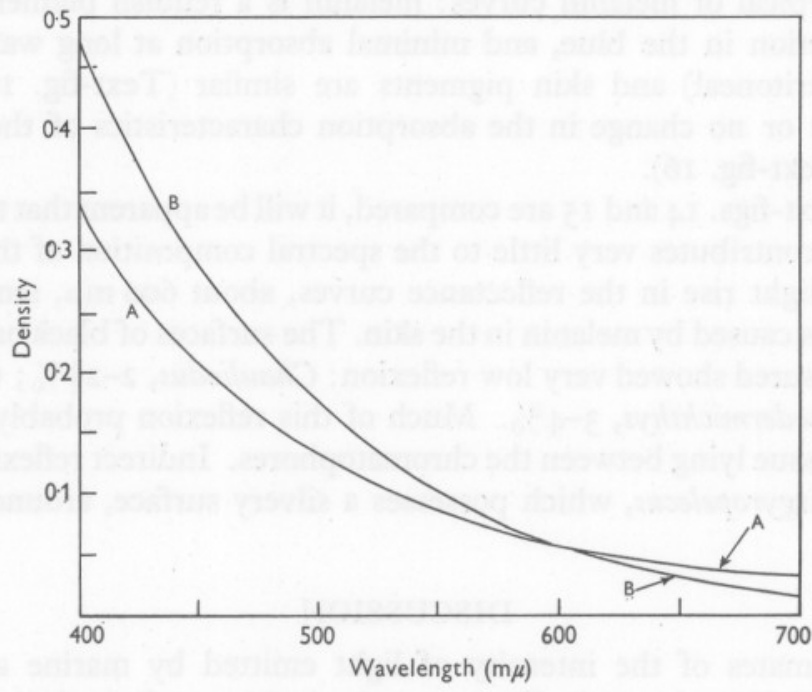

Text-fig. 15. Absorption characteristics of the melanin pigment from the integument of Gonostoma denudatum. I cm cuvette in Unicam spectrophotometer, S.P. 500. A, in boricborate buffer, $\mathrm{pH} 9$; $\mathrm{B}$, in ethylene chlorhydrin.

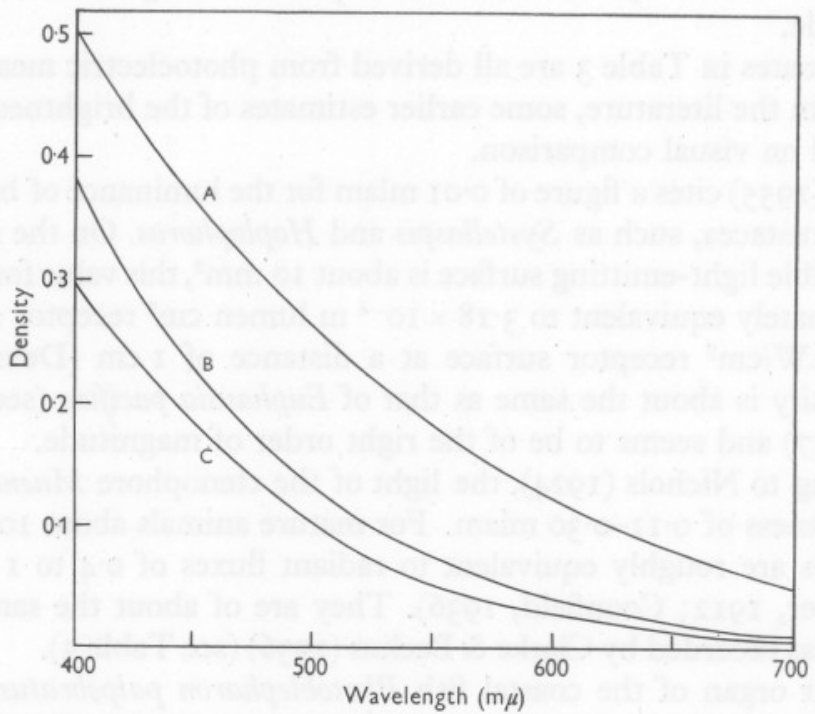

Text-fig. 16. Absorption characteristics of the melanin pigment from the deep-sea fish Cyclothone livida. A, from entire animal, in ethylene chlorhydrin; B, formol-preserved integument, in ethylene chlorhydrin; c, viscera, in ethylene chlorhydrin. I cm cuvette in Unicam spectrophotometer, S.P. 500. 
relative luminous efficiency of radiation (human scotopic vision). An estimation of equivalent radiant flux is about $3 \times 10^{-4} \mu \mathrm{W} / \mathrm{cm}^{2}$ receptor surface at a distance of $\mathrm{I} \mathrm{cm}$.

The light of most pelagic animals is blue in colour, although there are notable exceptions. Actual measurements of spectral composition give maximal emission peaks (approximately) as follows: Gonyaulax polyedra, $478 \mathrm{~m} \mu$ (Hastings \& Sweeney, 1957); Atolla wyvillei, $470 \mathrm{~m} \mu$; Vogtia glabra, $470 \mathrm{~m} \mu$; Beroë ovata, 5 Iо $\mathrm{m} \mu$; Euphausia pacifica, $476 \mathrm{~m} \mu$ (Kampa \& Boden, 1957); Pyrosoma atlantica, $482 \mathrm{~m} \mu$ (Kampa \& Boden, 1957). Of these animals only the light of Beroë ovata is green. Symbiotic bacteria from the deep-sea fish Coelorhynchus (kishinonyei?) emit light with a maximum $\nu=21,200 \mathrm{~cm}^{-1}$ or $\lambda=472 \mathrm{~m} \mu$ (Takase, in Harvey, 1952). The bacterial light of Malacocephalus laevis, another macrourid, is said to have an emission maximum around 5Io $\mathrm{m} \mu$ (Haneda, in Harvey, I952). Harvey (1952) cites some instances of lights of other colours in pelagic animals: Thaumatolampas diadema is a squid having photophores emitting red light; Echiostoma tanneri is a teleost possessing cheek organs which shine with a pink or blue glow (cf. Beebe \& Crane, 1939). The smaller photophores of Echiostoma and those of Argyropelecus olfersi are said to emit a yellowish or yellow-green light (see Harvey, 1952).

Attenuation of light from a point source in sea water depends both upon distance (operation of the inverse square law) and absorption (given by the extinction coefficient). Clarke \& James (1939) give the following values for absorption in (preserved) Sargasso Sea water:

\begin{tabular}{ccc}
$\lambda(\mathrm{m} \mu)$ & $\begin{array}{c}\text { Transmission } / \mathrm{m} \\
(\%)\end{array}$ & Remarks \\
405 & $97 \cdot 2$ & Filtered \\
436 & 99 & Filtered \\
490 & $97 \cdot 2$ & Filtered \\
\hline & 90 & Shaken \\
505 & $95 \cdot 5$ & Filtered \\
546 & $95 \cdot 8$ & Filtered \\
550 & 87 & Shaken
\end{tabular}

A measurement made at sea of surface water (Sargasso Sea) gave a value of $96 \cdot \mathrm{I} \%$ at $550 \mathrm{~m} \mu$.

Jerlov (195I), from measurements at sea, found that transmission/m depth for blue daylight in the Atlantic Ocean varied from a minimum of $91.5 \%$ (surface) to a maximum of $98 \%$ (at $25-50 \mathrm{~m}$ ) (various stations). Selected values for transmission at various stations $(0-50 \mathrm{~m})$ are

$\begin{array}{cc}\lambda(\mathrm{m} \mu) & \begin{array}{c}\text { Mean transmission/m } \\ \text { depth }(\%)\end{array} \\ 400 & 93 \cdot 3-96 \cdot 8 \\ 475 & 95 \cdot 6-96 \cdot 8 \\ 500 & 95 \cdot 1-96 \cdot 8 \\ 525 & 93 \cdot 4-94 \cdot 9 \\ 550 & 91 \cdot 3-93 \cdot 7\end{array}$


It would seem, then, that transmission in oceanic waters for blue and green light (spectral range of about 460-5 I0 $\mathrm{m} \mu$ ) lies between 9I and 99\% (transmission/m depth), and for purposes of illustration, arbitrary limits of I and Io $\%$ absorption $/ \mathrm{m}$ depth have been selected, as representing two extremes for oceanic water.

Estimates of light intensities at various distances from a point source are illustrated in Text-fig. I7. The light intensities illustrated are selected from Table 3, and represent the maximal measured output of several luminescent animals in terms of radiant flux $/ \mathrm{cm}^{2}$ receptor surface at an initial distance of I cm, viz. of radiolarians Cytocladus and Aulosphaera; a siphonophore Vogtia spinosa; a scyphomedusan Atolla wyvillei; ctenophores Berö̈ ovata and Mnemiopsis leidyi; crustaceans Euphausia pacifica and Acanthephyra purpurea; Pyrosoma; and the lantern-fish Myctophum punctatum. The three curves in each figure show decrease of light intensity with distance according to the inverse square law alone, and decrease according to the inverse square law in sea water having transmission values of 99 and $90 \% / \mathrm{m}$ depth. For these values it will be observed that the curve for $90 \%$ transmission only begins to diverge markedly from that for the inverse square law at distances greater than $10 \mathrm{~m}$, and that for $99 \%$ transmission, above $100 \mathrm{~m}$.

It is unfortunate that so little information exists about visual threshold or minimal intensities that can be perceived by marine animals. Earlier estimates of visual threshold for fish have made use of Grundfest's observations (1932) on Lepomis, a freshwater fish. These indicated that the lower limits of light intensity for fish vision were similar to those for the human eye, viz. $\mathrm{I} \times 1 \mathrm{I}^{-6} \mathrm{mlam}$. For an estimated pupillary area of $0.1 \mathrm{~cm}^{2}$, equivalent radiant flux would be about $\mathrm{I} \cdot 2 \times \mathrm{IO}^{-8} \mu \mathrm{W}$ falling into one eye. Lepomis is most sensitive to the green region of the spectrum, around 530-550 $\mathrm{m} \mu$ (Grundfest, 1932; Clarke I936; Strickland, I957).

The threshold of the human eye, when dark-adapted, for a small steady light source, has been estimated at 200 quanta/sec at 5 Io $\mathrm{m} \mu$ (selected from values ranging from $\mathrm{I} 70$ to 830 quanta/sec) (Pirenne, I956). For a just detectable flash of duration $\geqslant I \mathrm{sec}$, the human eye needs 200 quanta $=8 \times 10^{-10} \mathrm{erg}$ to fall in the pupil, area $0.5 \mathrm{~cm}^{2}$ in I sec. Pirenne (I956) suggests that the high retinal sensitivity of man is similar to that of other rod-bearing vertebrates, and that some invertebrates may also be equally sensitive. Dendrocoelum lacteum, a fresh-water planarian, responds to light having an energy flux of $15 \times \mathrm{IO}^{-9} \mathrm{erg} / \mathrm{sec}$ falling in one eye (Pirenne \& Marriott, I955).

The brightest luminescent animals known in the sea are ctenophores, Pyrosomas, and the deep-sea fish Searsia, all of which have a measured light output in excess of $2 \times 10^{-7} \mu \mathrm{W} / \mathrm{cm}^{2}$ receptor surface at a distance of $\mathrm{I} \mathrm{m}$. In the first two, luminescence is intracellular; the latter discharges a bright luminous secretion. 


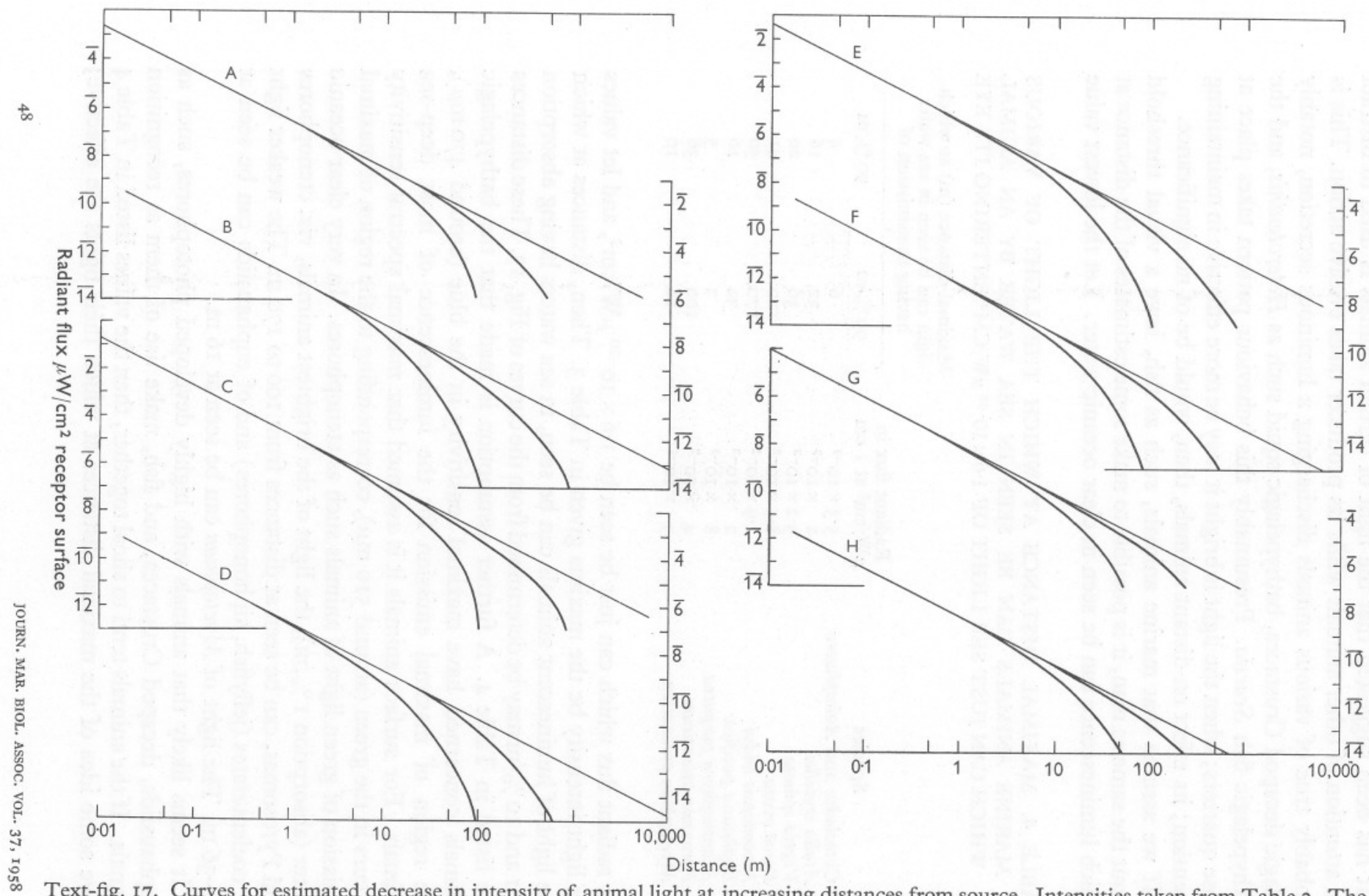

Text-fig. 17. Curves for estimated decrease in intensity of animal light at increasing distances from source. Intensities taken from Table 3. The three curves in each figure refer, from above downwards, to decrease from a point source according to the inverse square law alone; decrease in sea water having an absorption of $\mathrm{I} \% / \mathrm{m}$; and decrease in sea water having an absorption of ro \%/m. A, Vogtia spinosa; в, Beroë ovata; c, Mnemiopsis leidyi; D, Atolla wyvillei and Euphausia pacifica; E, Pyrosoma atlanticum; F, Myctophum punctatum; G, Acanthephyra purpurea; H, Cytocladus and Aulosphaera. Scale for A on left, for B on right, and so on. 
It has been suggested that the light of certain animals is used to distract the attention of other animals while its producer takes evasive action. This is probably true of various animals discharging a luminous secretion, notably pelagic decapod Crustacea, bathypelagic squid such as Heteroteuthis, and the bathypelagic fish Searsia. Presumably this behaviour pattern takes place at close quarters; when the light is bright it may be more effective in maintaining attention; its effect on distant animals, then, would be of no significance.

If we assume that marine animals, such as fish, have a visual threshold about the same as man, it is possible to make some estimates of the distance at which luminescence can be seen in clear oceanic water. Let the lowest value

TABLE 4. MAXIMAL DISTANCE AT WHICH THE LIGHT OF VARIOUS MARINE ANIMALS CAN BE SEEN IN SEA WATER BY AN ANIMAL WHICH CAN JUST SEE LIGHT OF $1.6 \times 10^{-10} \mu \mathrm{W} / \mathrm{CM}^{2}$ ENTERING ITS EYE

\begin{tabular}{|c|c|c|c|}
\hline \multirow[b]{2}{*}{ Species } & \multirow{2}{*}{$\begin{array}{l}\text { Radiant flux in } \\
\mu \mathrm{W} / \mathrm{cm}^{2} \text { at } \mathrm{I} \mathrm{cm}\end{array}$} & \multicolumn{2}{|c|}{$\begin{array}{l}\text { Maximal distance }(\mathrm{m}) \text { at which } \\
\text { light can be seen in sea water } \\
\text { having transmission of }\end{array}$} \\
\hline & & $99 \% / \mathrm{m}$ & $90 \% / m$ \\
\hline Cytocladus and Aulosphaera & $5.3 \times 10^{-5}$ & 6 & 4 \\
\hline Atolla wyvillei & $2 \times 10^{-3}$ & 32 & $\begin{array}{l}4 \\
16\end{array}$ \\
\hline Vogtia spinosa & $3.2 \times 10^{-3}$ & 36 & 20 \\
\hline Beroë ovata & $8.5 \times 10^{-2}$ & 120 & $4 \mathrm{I}$ \\
\hline Mnemiopsis leidyi & $I \cdot 9 \times 10^{-1}$ & 170 & 50 \\
\hline Euphausia pacifica & $2 \times 10^{-3}$ & 32 & 16 \\
\hline Acanthephyra purpurea & $8 \times 10^{-5}$ & 7 & 5 \\
\hline Pyrosoma atlanticum & $4 \times 10^{-2}$ & I00 & 36 \\
\hline Myctophum punctatum & $5 \times 10^{-4}$ & I6 & Io \\
\hline
\end{tabular}

for radiant flux which can just be seen be $\mathrm{I} \cdot 6 \times \mathrm{IO}^{-10} \mu \mathrm{W} / \mathrm{cm}^{2}$, and let values for light intensity be the maxima given in Table 3 . Then, distances at which the light of luminescent animals can be seen, in sea waters having absorption of $\mathrm{I}$ and $10 \% / \mathrm{m}$ may be determined from the curves of Fig. I7. These distances are listed in Table 4. A further assumption is made that the bathypelagic animals concerned have maximal sensitivity in the blue (around $470 \mathrm{~m} \mu$ ), the region of maximal emission for the luminescence of most deep-sea animals. For surface animals it is assumed that maximal spectral sensitivity occurs in the green (around $510 \mathrm{~m} \mu$ ), corresponding to the region of maximal emission of green light of animals such as ctenophores. In very clear oceanic water (absorption $\mathrm{I} \% / \mathrm{m}$ ), the light of the brightest animals, viz. ctenophores and Pyrosomas, can be seen at distances from 100 to $170 \mathrm{~m}$. The weaker light of coelenterates (jellyfish, siphonophores) and of euphausiids can be seen at $32-36 \mathrm{~m}$. The light of Myctophum can be seen at $16 \mathrm{~m}$.

It seems likely that animals with highly developed photophores, such as euphausiids, decapod Crustacea, and fish, make use of them as recognition signals. If the animals tend to shoal together, then the values listed in Table 4 give some idea of the maximal distances at which their lights are effective; 
they can also be correlated with estimates of population density. Dennell (I955) has made an estimate of the distance at which the light from the photophores of a deep-sea shrimp can be seen by another shrimp. He gives a minimal value of 0.01 mlam for brightness, and he quotes values of $\mathrm{I} \times 1 \mathrm{IO}^{-6}$ to $\mathrm{I} \times \mathrm{IO}^{-7} \mathrm{mlam}$ for visual threshold of a crustacean (Cambarus?). Using an extinction coefficient of $u_{\nu}=0.0920$ for clear oceanic water, he has estimated that the light of decapod photophores may well be mutually perceived at distances of roo m. Assume that the eye of a shrimp has an area of $0.05 \mathrm{~cm}^{2}$; then the minimal light entering that eye which can just be seen has an intensity around $\mathrm{I} \times \mathrm{IO}^{-8} \mu \mathrm{W}$. One shrimp can be treated as a point source, the light from which decreases with distance according to the inverse square law. For waters having transmissions of 99 and $90 \% / \mathrm{m}$, the estimated maximal distance at which one shrimp could see the light of another shrimp is about $\mathrm{I} \mathrm{m}$. If the visual threshold of the shrimp lies at about the same level as that of man (dark adapted), the equivalent maximal distance would lie around I6-32 m.

Estimates have been made of the average spatial distribution of deep-sea shrimp, based on towing data. It is suggested that, if the animals are evenly distributed, Systellaspis debilis occurs at intervals of about $14 \mathrm{~m}$ and Hoplophorus grimaldii at $40 \mathrm{~m}$. For a visual threshold value of $2 \times 10^{-7} \mu \mathrm{W} / \mathrm{cm}^{2}$, these distances are excessive for mutual perception of photophore luminescence. It is known that euphausiids occur in shoals, and, from the estimates given above, it can be argued that their lights can be mutually seen at distances of about $\mathrm{I} \mathrm{m}$. Since these animals appear to flash spontaneously in their natural habitat, it is likely that their lights tend to promote shoaling. There are a great many variables in these estimates. Thus, the photophores possess lenses, the optical properties of which may greatly alter the geometry of the light beam, and firmer values are desirable for visual threshold.

There remains for speculation a consideration of the optics of photogenic organs. Many photogenic organs obviously lack focusing devices, and the light which they emit radiates outwards more or less uniformly over some solid angle determined by the morphological configuration of the light organs. Various examples are the unicellular radiolarians and dinoflagellates; luminescent tissues of coelenterates and ctenophores; light organs of Pyrosomas; organs of Pesta (luminous liver tubules) of Sergestes; disc-like organs of squid Abralia and Leachia; luminous tentacles and bulbs of bathypelagic teleosts. From organs of this kind it is reasonable to assume that the light will conform to the inverse square law. In sea water, intensity will decrease in a predictable manner according to distance and transparency of the water.

Many other animals possess very complex light organs, containing reflectors and lens systems. Very little is known about the optics of these structures. If the action of the lenses is to produce a parallel beam of light, then intensity would fall off much less rapidly with distance. Trojan (1907) has ventured some conclusions concerning the optic properties of the photophore of the 
euphausiid Nyctiphanes couchi. He has found that the light is brought to a focal point immediately in front of the light organ; the light, therefore, could radiate forth from that focal point as a point source. In order to get further information about this effect, it would be desirable to make simultaneous measurements at varous distances of the light from organized photophores, containing lenses, if a suitable preparation or preparations could be found.

Data have been presented for reflectance of light from some deep-sea animals (Text-figs. I3 and I4, pp. 736 and 737). Reflexion curves for deep-sea fish Cyclothone and Chauliodus are fairly flat in the visual range $(400-700 \mathrm{~m} \mu$ ), so that there is little change in relative reflexion at different wave-lengths (Text-fig. I4). Quite otherwise is the reflexion curve for the deep-sea shrimp Acanthephyra (Text-fig. 13). Reflexion from the integument of this animal is minimal in the blue, below $500 \mathrm{~m} \mu$, and maximal in the red, above $650 \mathrm{~m} \mu$. Oceanic waters are most transparent to blue light, with a maximum around $475 \mathrm{~m} \mu$ and, owing to differential absorption, this is the only effective light in deeper regions (Text-fig. I8).

The relative spectral energy of light reflected from a surface depends on the reflectance characteristics of that surface, and the relative spectral composition of the incident light. In Text-figs. I8 and 19 are presented curves for relative spectral composition of light in clear oceanic water (from Sverdrup, Johnson \& Fleming, 1942), relative spectral composition of Cypridina light (from Coblentz \& Hughes, 1926), diffuse spectral reflectance of Acanthephyra multispina, and product curves (c) of incident light and reflectance. It will be seen that the integument of Acanthephyra reflects least light in the blue region of the spectrum, and it is this region that contains most of the energy of daylight and luminescent light in the sea. The colour of Acanthephyra thus seems well suited to reducing reflexion, and therefore the animal's chance of being seen.

The following estimates for Acanthephyra are presented to illustrate some of the factors involved in computing light reflexion from the surface of animals. Assume a luminescent fish has a light output of $\mathrm{I} \times \mathrm{IO}^{-8} \mu \mathrm{W} / \mathrm{cm}^{2}$ receptor surface at $\mathrm{I} \mathrm{m}$ distance, and let this light be blue, with maximal emission at $480 \mathrm{~m} \mu$. An Acanthephyra, $9 \mathrm{~cm}$ long, has a surface area, on one side, of approximately $\mathrm{I}_{2} \mathrm{~cm}^{2}$; at $480 \mathrm{~m} \mu$ let its reflexion be $10 \%$. At $\mathrm{I} \mathrm{m}$ distance, that Acanthephyra will receive $\mathrm{I} \times \mathrm{IO}^{-8} \mu \mathrm{W} / \mathrm{cm}^{2}$ body surface, and reflect back $\mathrm{I} \cdot 2 \times 10^{-8} \mu \mathrm{W}$. At a distance of $\mathrm{I} \mathrm{m}$, estimated radiant flux reflected from the surface of Acanthephyra will be only about $2.5 \times \mathrm{IO}^{-13} \mu \mathrm{W} /$ $\mathrm{cm}^{2}$ receptor surface, well below visual sensitivity of known photoreceptors. In terms of the above energy values, the Acanthephyra would have to be within about $20-30 \mathrm{~cm}$ of the fish to be seen by the latter. Since the darkcoloured bathypelagic fishes also have very low reflectance throughout the visible spectrum (Text-fig. I4), similar considerations would apply to these animals. 


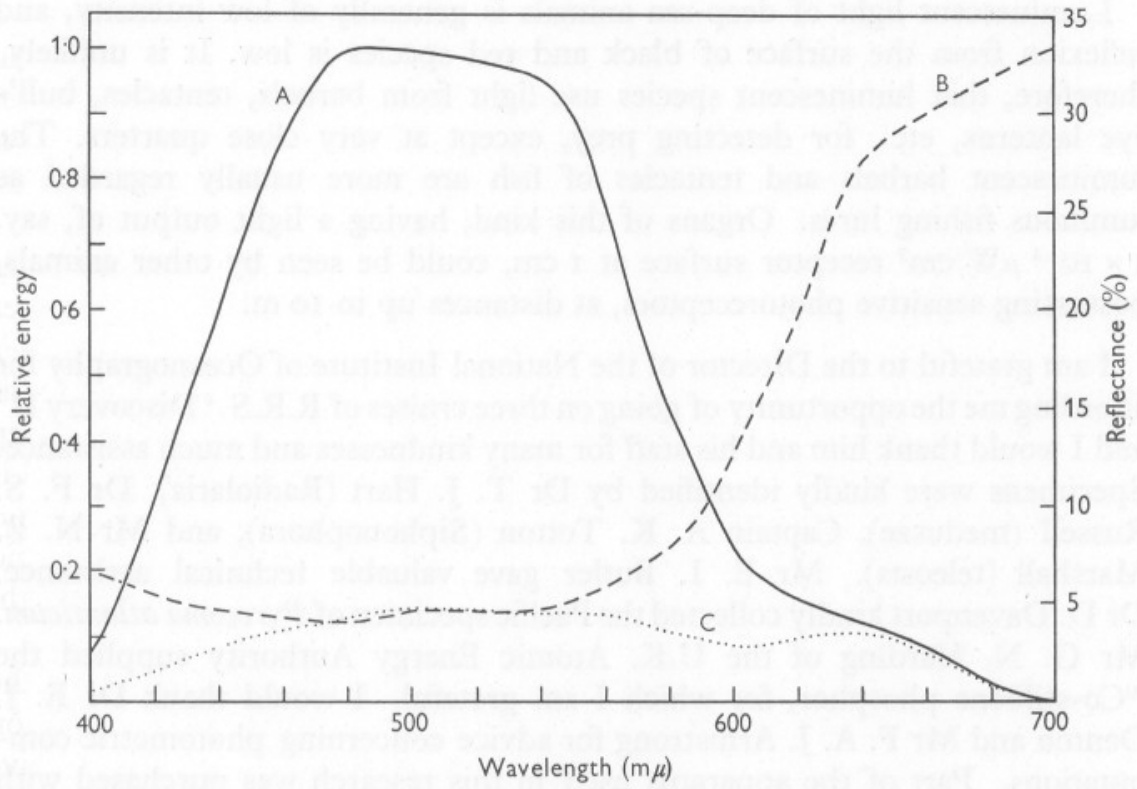

Text-fig. 18. Curves: A, relative spectral composition of daylight transmitted through clear oceanic water, scale for ordinates on left (from Sverdrup, Johnson \& Fleming, 1942); B, spectral reflexion curve for Acanthephyra; c, product curve of A and B. Scale for B and C on right.

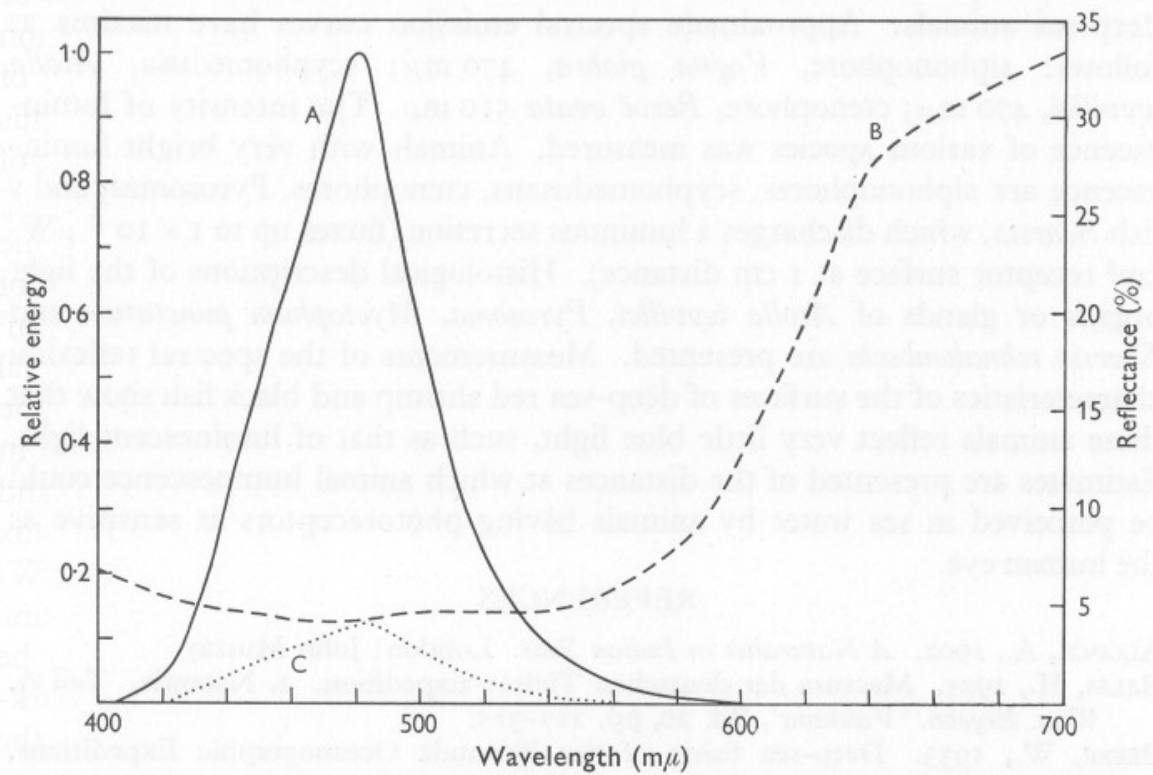

Text-fig. 19. A, relative spectral composition of Cypridina light (from Coblentz \& Hughes, 1926). B, spectral reflexion curve for Acanthephyra; c, product curve of A and B. Scale for A on left; for $\mathrm{B}$ and $\mathrm{C}$ on right. 
Luminescent light of deep-sea animals is generally of low intensity, and reflexion from the surface of black and red species is low. It is unlikely, therefore, that luminescent species use light from barbels, tentacles, bull's eye lanterns, etc., for detecting prey, except at very close quarters. The luminescent barbels and tentacles of fish are more usually regarded as luminous fishing lures. Organs of this kind, having a light output of, say, $\mathrm{I} \times \mathrm{IO}^{-4} \mu \mathrm{W} / \mathrm{cm}^{2}$ receptor surface at $\mathrm{I} \mathrm{cm}$, could be seen by other animals, possessing sensitive photoreceptors, at distances up to Io $\mathrm{m}$.

I am grateful to the Director of the National Institute of Oceanography for affording me the opportunity of going on three cruises of R.R.S. 'Discovery II' and I would thank him and his staff for many kindnesses and much assistance. Specimens were kindly identified by Dr T. J. Hart (Radiolaria), Dr F. S. Russell (medusae), Captain A. K. Totton (Siphonophora), and Mr N. B. Marshall (teleosts). Mr E. I. Butler gave valuable technical assistance. Dr D. Davenport kindly collected the Pacific specimen of Pyrosoma atlanticum. Mr G. N. Harding of the U.K. Atomic Energy Authority supplied the ${ }^{60} \mathrm{Co}$-stilbene phosphor, for which I am grateful. I would thank Dr E. J. Denton and Mr F. A. J. Armstrong for advice concerning photometric computations. Part of the apparatus used in this research was purchased with grants from the Royal Society.

\section{SUMMARY}

Miscellaneous observations have been made on the luminescence of pelagic deep-sea animals. Approximate spectral emission curves have maxima as follows: siphonophore, Vogtia glabra, $470 \mathrm{~m} \mu$; scyphomedusa, Atolla wyvillei, $470 \mathrm{~m} \mu$; ctenophore, Beroë ovata 5 Iо $\mathrm{m} \mu$. The intensity of luminescence of various species was measured. Animals with very bright luminescence are siphonophores, scyphomedusans, ctenophores, Pyrosomas, and a fish Searsia, which discharges a luminous secretion (fluxes up to $\mathrm{I} \times \mathrm{IO}^{-1} \mu \mathrm{W} /$ $\mathrm{cm}^{2}$ receptor surface at $\mathrm{I} \mathrm{cm}$ distance). Histological descriptions of the light organs or glands of Atolla wyvillei, Pyrosoma, Myctophum punctatum and Searsia schnakenbecki are presented. Measurements of the spectral reflexion characteristics of the surfaces of deep-sea red shrimp and black fish show that these animals reflect very little blue light, such as that of luminescent light. Estimates are presented of the distances at which animal luminescence could be perceived in sea water by animals having photoreceptors as sensitive as the human eye.

\section{REFERENCES}

ALCOCK, A., 1902. A Naturalist in Indian Seas. London: John Murray.

BALSS, H., 1925. Macrura der deutschen Tiefsee-Expedition. 2. Natantia, Teil A. Wiss. Ergebn. 'Valdivia', Bd. 20, pp. 217-315.

BeEBE, W., 1933. Deep-sea fishes of the Bermuda Oceanographic Expeditions. Family Alepocephalidae. Zoologica, N.Y., Vol. 16, No. 2, pp. 13-93.

- 1935. Half Mile Down. London: John Lane. 
BeEbe, W. \& Crane, J., 1939. Deep-sea fishes of the Bermuda Oceanographic Expeditions. Family Melanostomiatidae. Zoologica, N.Y., Vol. 24, pp. 65-238.

BENnetT, F. D., 1840. Narrative of a Whaling Voyage Round the Globe from the year I833 to I836. 2 vols. London: Richard Bentley.

BerRILL, N. J., I950 a. The Tunicata: with an account of the British species. London: Ray Society.

— 1950b. Budding in Pyrosoma. F. Morph., Vol. 87, pp. 537-52.

Bigelow, H. B., I9I2. The ctenophores. Bull. Mus. comp. Zool. Harv., Vol. 54, pp. 369-404.

Bigelow, H. B. \& Sears, M., 1937. Siphonophorae. Rep. Danish oceanogr. Exped. Medit., Vol. 2, Biology, No. II, H. 2, I44 pp.

BRANDT, K., I885. Die Koloniebildenden Radiolarien (Sphaerozoëen) des Golfes von Neapel und der angrenzenden Meeresabschnitte. Fauna Flora Neapel, Monogr. 13, pp. 136-39.

Brauer, A., 1906. Die Tiefsee-Fische. I. Systemischer Teil. Wiss. Ergebn. 'Valdivia', Bd. I5, Lief. I, 432 pp.

- 1908. Die Tiefsee-Fische. II. Anatomischer Teil. Wiss. Ergebn. 'Valdivia', Bd. I5, Lief. 2, 266 pp.

BrIEN, P., I948. Embranchement des Tuniciers. In Traité de Zoologie, ed. P.-P. Grassé. T. II, p. 757.

Buchner, P., I9I4. Sind die Leuchtorgane Pilzorgane? Zool. Anz., Bd. 45, pp. I7-2I.

- 1953. Endosymbiose der Tiere mit pflanzlichen Mikroorganismen. Basel/Stuttgart: Verlag Birkhäuser.

Burghause, F., 1914. Kreislauf und Herzschlag bei Pyrosoma giganteum nebst Bemerkungen zum Leuchtvermögen. Z. wiss. Zool., Bd. I08, pp. 430-97.

Caullery, M., I952. Parasitism and Symbiosis. Trans. A. M. Lysaght. London: Sidgwick and Jackson.

CHACE, F. A., JR., I940. Plankton of the Bermuda Oceanographic Expeditions. IX. The bathypelagic Caridean Crustacea. Zoologica, N.Y., Vol. 25, pp. II7-209.

Chang, J. J., I954. Analysis of the luminescent response of the ctenophore, Mnemiopsis leidyi, to stimulation. F. cell. comp. Physiol., Vol. 44, pp. 365-94.

Chun, C., I880. Die Ctenophoren des Golfes von Neapel und der angrenzenden Meeresabschnitte. Fauna Flora Neapel, Monogr. I, 313 pp.

ClARKE, G. L., 1936. Light penetration in the western North Atlantic and its application to biological problems. Rapp. Cons. Explor. Mer, Vol. Ior, pt. 2, No. 3, I4 pp.

ClaRkE, G. L. \& BACKUS, R. H., 1956. Measurements of light penetration in relation to vertical migration and records of luminescence of deep-sea animals. Deep-Sea Res., Vol. 4, pp. I-I4.

ClARKE, G. L. \& JAMES, H. R., I939. Laboratory analysis of the selective absorption of light by sea water. F. opt. Soc. Amer., Vol. 29, pp. 43-55.

Coblentz, W. W. \& Hughes, C. W., I926. Spectral energy distribution of the light emitted by plants and animals. Sci. Pap. U.S. Bur. Stand., Vol. 21, pp. 52I-34 (no. 538 ).

Coonfield, B. R., 1936. Apical dominance and polarity in Mnemiopsis leidyi, Agassiz. Biol. Bull., Woods Hole, Vol. 70, pp. 460-7I.

Dahlgren, U., I9I6. The production of light by animals. F. Franklin Inst., Vol. I8I, pp. 805-43.

Davenport, D. \& Nicol, J. A. C., 1955. Luminescence in Hydromedusae. Proc. roy. Soc., B, Vol. I44, pp. 399-4II.

DEANIN, G. G. \& STEGGERDA, F. R., I 948 . Use of the spectrophotometer for measuring melanin dispersion in the frog. Proc. Soc. exp. Biol., N.Y., Vol. 67, pp. IOI-4. 
DENNELL, R., I940. On the structure of the photophores of some Decapod Crustacea. 'Discovery' Rep., Vol. 20, pp. 307-82.

- I955. Observations on the luminescence of bathypelagic Crustacea Decapoda of the Bermuda area. F. Linn. Soc. (Zool.), Vol. 42, pp. 393-406.

Dubors, R., I914. La Vie et la Lumière. Paris: Felix Alcan.

Edwards, E. A. \& Duntley, S. Q., 1939. The pigments and color of living human skin. Amer. F. Anat., Vol. 65, pp. I-33.

EMERY, C., I884. Intorno alle macchie splendenti della pelle nei pesci del genere Scopelus. Mitt. zool. Sta. Neapel, Bd. 5, pp. 47I-82.

Eymers, J. G. \& VAN SCHOUWENBURG, K. L., I937. On the luminescence of bacteria. III. Further quantitative data regarding spectra connected with bioluminescence. Enzymologia, Vol. 3, pp. 235-4I.

FRASER-BRUNNER, A., I949. A classification of the fishes of the family Myctophidae. Proc. zool. Soc. Lond., Vol. II8, pp. IoI9-Iro6.

Goodwin, T. W., I952. The Comparative Biochemistry of the Carotenoids. London: Chapman and Hall.

GorTNER, R. A., I9II. Studies on melanin. I. Methods of isolation. The effect of alkali on melanin. F. biol. Chem., Vol. 8, pp. 34I-63.

GrundFest, H., I932. The sensibility of the sun-fish, Lepomis, to monochromatic radiation of low intensities. F. gen. Physiol., Vol. 15, pp. 307-28.

HaECKer, V., I908. Tiefsee-Radiolarien. Wiss. Ergebn. 'Valdivia', Bd. I4, Lief. I, pp. IIIII3.

Harvey, E. N., I922. The production of light by the fishes Photoblepharon and Anomalops. Pap. Tortugas Lab., Vol. 8, pp. 43-60.

- I952. Bioluminescence. New York: Academic Press.

- 1955. Survey of luminous organisms. In The Luminescence of Biological Systems, ed. F. H. Johnson, pp. I-24. Wash., D.C. : Amer. Ass. Adv. Sci.

Hastings, J. W. \& SWEeney, B. M., I957. The luminescent reaction in extracts of the marine dinoflagellate, Gonyaulax polyedra. F. cell. comp. Physiol., Vol. 49, pp. 209-15.

HICKLING, C. F., I926. A new type of luminescence in fishes. II. F. mar. biol. Ass. U.K., Vol. I4, pp. 495-507.

Huxiey, T. H., I851. Observations upon the anatomy and physiology of Salpa and Pyrosoma. Phil. Trans., year I851, pt. 2, pp. 567-93.

Ihle, J. E. W., 1910. Die Thaliaceen (einschliesslich Pyrosomen) der SibogaExpedition. Siboga Exped., Monogr. 56, d, 55 pp.

JerLov, N. G., I95I. Optical studies of ocean waters. Rep. Swedish deep-sea Exped. Vol. 3, Physics and Chem., Fasc. I, 59 pp.

JuLIN, C., I9I2. Recherches sur le développement embryonnaire de Pyrosoma giganteum Les. I. Aperçu général de l'embryogènese. Les cellules du testa et le développement des organes lumineux. Zool. Fb., Suppl. 15, Bd. 2, pp. 775863.

- I913. The specific histological characters of the 'luminous cells' of Pyrosoma giganteum and of Cyclosalpa pinnata. Rep. Brit. Ass., 1912, pp. 492-3.

KAMPA, E. M. \& BodEN, B. P., I957. Light generation in a sonic-scattering layer. Deep-Sea Res., Vol. 4, pp. 73-92.

KARRER, P. \& JUCKER, E., I948. Carotenoide. Basel: Verlag Birkhäuser.

KeMP, S., I9I0. The Decapoda Natantia of the coasts of Ireland. Sci. Invest. Fish.

$B r$. Ire., Year 1908, No. I, 190 pp.

1939. On Acanthephyra purpurea and its allies. Ann. Mag. nat. Hist., Ser. II, Vol. 4, pp. 568-79. 
KramP, P. L., 1947. Medusae: Part III. Trachylina and Scyphozoa, with zoogeographical remarks on all the medusae of the Northern Atlantic. Dan. IngolfExped., Vol. 5, No. I4, 66 pp.

Kramp, P. L., I957. Hydromedusae from the Discovery Collections. 'Discovery' Rep., Vol. 29, pp. I-I28.

KREFFT, G., 1953. Ichthyologische Mitteilungen aus dem Institut für Seefischerei der Bundesforschungsanstalt für Fischerei. II. 3. Eine neue Searsia-Art (Isopondyli, Searsidae) aus isländischen Gewässern. Zool. Anz., Bd. I5 I, pp. 259-66.

Krumbach, T., 1927. Ctenophora. Tierw. N.-u. Ostsee, Teil 3, f, pp. I-50 (Leif. 7).

LEA, A. J., I945. A neutral solvent for melanin. Nature, Lond., Vol. 156, p. 478.

Leloup, E., 1955. Siphonophores. Rep. Sars N. Atl. Deep-Sea Exped., Vol. 5, No. II, 24 pp.

Marshall, N. B., 1954. Aspects of Deep Sea Biology. London: Hutchinson's.

Maul, G. E., I948. Monografia dos Peixes do Museu Municipal do Funchal Ordem Isospondyli. Bol. Mus. Funchal, No. 3, Art. 5, pp. I-4I.

Mayer, A. G., I9I2. Ctenophores of the Atlantic Coast of North America. Publ. Carneg. Inst., No. 162,58 pp.

Metcalf, M. M. \& Hopkins, H. S., I919. Pyrosoma.-A taxonomic study based upon the collections of the United States Bureau of Fisheries and the United States National Museum. Bull. U.S. nat. Mus., Vol. 2, pp. 195-275.

Moore, A. R., I924. Luminescence in Mnemiopsis. F. gen. Physiol., Vol. 6, pp. 403-I2.

Mortensen, T., I9I2. Ctenophora. Dan. Ingolf-Exped., Vol. 5, pt. 2, 95 pp.

Moseley, H. N., I892. Notes by a Naturalist. An Account of Observations Made During the Voyage of H.M.S. 'Challenger'. London: John Murray.

Murray, Sir John \& HJort, J., I9I2. The Depths of the Ocean. London: Macmillan.

Neumann, G., I934. Tunicata. Thaliaceae. Handb. Zool., Berl., Bd. 5, pt. 2, pp. 226-33.

Nichols, E. L., 1924. The brightness of marine luminescence. Science, Vol. 60, pp. 592-93.

Nicol, J. A. C., I955a. Physiological control of luminescence in animals. In The Luminescence of Biological Systems, ed. F. H. Johnson, pp. 299-32I. Wash., D.C.: Amer. Ass. Adv. Sci.

- 1955b. Nervous regulation of luminescence in the sea pansy Renilla köllikeri. F. exp. Biol., Vol. 32, pp. 619-35.

- 1957a. Luminescence in polynoids. II. Different modes of response in the elytra. F. mar. biol. Ass. U.K., Vol. 36, pp. 26I-69.

- I957b. Spectral composition of the light of polynoid worms. F. mar. biol. Ass. U.K., Vol. 36, pp. 529-38.

- 1957c. Spectral composition of the light of Chaetopterus. F. mar. biol. Ass. U.K., Vol. 36, pp. 629-42.

I958a. Luminescence in polynoids. IV. Measurements of light intensity. F. mar. biol. Ass. U.K., Vol. 37, pp. 33-4I.

- 1958b. Spectral composition of the light of Pholas dactylus L. F. mar. biol. Ass. U.K., Vol. 37, pp. 43-7.

Norman, J. R., 1930. Oceanic fishes and flatfishes collected in 1925-1927. 'Discovery' Rep., Vol. 2, pp. 26I-370.

OHshima, H., I9I I. Some observations on the luminous organs of fishes. F. Coll. Sci. Tokyo, Vol. 27, Art. 15, 25 pp.

OKaDA, Y. K., I926. On the photogenic organ of the knight-fish (Monocentris japonicus (Houttuyn)). Biol. Bull., Woods Hole, Vol. 50, pp. 365-73.

PANCERI, P., I872. Études sur la phosphorescence des animaux marins. Ann. Sci.nat. (Zool.), T. 16, Ser. 5, Art. 8, 67 pp. 
PANCERI, P., I873. The luminous organs and light of Pyrosoma. Quart. F. micr. Sci., Vol. I3, N.S., pp. 45-5I.

Pantin, C. F. A., I952. The elementary nervous system. Proc. roy. Soc., B, Vol. I40, pp. I47-68.

ParR, A. E., 1937. Concluding report on fishes. Bull. Bingham ocearogr. Coll., Vol. 3, Art. 7, 68 pp.

- 195I. Preliminary revision of the Alepocephalidae, with the introduction of a new family, Searsidae. Amer. Mus. Novit., No. I531, 21 pp.

PÉron, F., I804. Mémoire sur le nouveau genre Pyrosoma. Ann. Mus. Hist. nat. Paris, T. 4, p. 437 .

PIERANTONI, U., I92I. Gli organi luminosi simbiotici ed il loro ciclo ereditario in Pyrosoma giganteum. Pubbl. Staz. zool. Napoli, Vol. 3, pp. I9I-222.

Pirenne, M. H., I956. Physiological mechanisms of vision and the quantum nature of light. Biol. Rev., Vol. 31, pp. 194-24I.

Pirenne, M. H. \& MARriotT, F. H. C., I955. Light sensitivity of the aquatic flatworm Dendrocoelum lacteum. Nature, Lond., Vol. 175, p. 642.

Polimanti, O., I9I I. Über das Leuchten von Pyrosoma elegans Les. Z. Biol., Bd. 55, pp. 505-29.

Russell, F. S., 1953. The Medusae of the British Isles. Cambridge University Press.

- 1958. A new species of Atolla. Nature, Lond., Vol. I8I, p. I8I I.

SCHRÖDER, O., 1907. Neue Radiolarien. Dtsch. SüdpolExped. Bd. 9 (Zoologie Bd. I), pp. 205-23.

Sears, M., 1954. Ctenophores in the Gulf of Mexico. Fish. Bull., U.S., Vol. 55, No. 89 , p. 297.

SERRA, J. A., 1946. Constitution of hair melanins. Nature, Lond., Vol. 157, p. 77 I.

SMYTH, J. R., JR., PORTER, J. W. \& Bohren, B. B., I95I. A study of pigments from red, brown, and buff feathers and hair. Physiol. Zoöl., Vol. 24, pp. 205-r6.

STECHE, O., 1907. Über leuchtende Oberflächenfische aus dem malayischen Archipel. Verh. dtsch. zool. Ges., Bd. I7, pp. 85-93.

Stephensen, K., 1923. Decapoda-Macrura excl. Sergestidae. Rep. Danish oceanogr. Exped. Medit., Vol. 2, Biol., No. 7, D. 3. 85 pp.

Steuer, A., I910. Planktonkunde. Leipzig und Berlin: B. N. Teubner.

StrickLand, J. D. H., I957. Solar radiation penetrating the ocean. Fish. Res. Bd Can. Mimeographed publication (File N 7-2-2 (7)).

Sverdrup, H. U., Johnson, M. W. \& Fleming, R. H., 1942. The Oceans: their Physics, Chemistry and General Biology. New York: Prentice-Hall.

Thompson, H., I948. Pelagic Tunicates of Australia. Melbourne: Commonwealth Council for Scientific and Industrial Research.

Totron, A. K., 1954. Siphonophora of the Indian Ocean, together with systematic and biological notes on related specimens from other oceans. 'Discovery' Rep., Vol. 27, pp. I-I62.

Trojan, E., 1907. Zur Lichtentwicklung in den Photosphärien der Euphausien. Arch. mikr. Anat., Bd. 70, pp. 177-89.

TUCKER, D. W., 1954. Report on the fishes collected by S. Y. "Rosaura" in the North and Central Atlantic, 1937-38. Part I. Families Carcharhinidae, Torpedinidae, Rosauridae (nov.), Salmonidae, Alepocephalidae, Searsidae, Clupeidae. Bull. Brit. Mus. (nat. Hist.), Vol. 2 (Zool.), pp. 163-239.

Wald, G., Nathanson, N., Jencks, W. P. \& TARR, E., I948. Crustacyanin, the blue carotenoid-protein of the lobster shell. Biol. Bull., Woods Hole, Vol. 95, pp. 249-50.

WaLsh, J. W. T., 1953. Photometry. London: Constable.

Young, J. Z., 1950. The Life of Vertebrates. Oxford: Clarendon Press. 